University of Nebraska - Lincoln

DigitalCommons@University of Nebraska - Lincoln

USGS Staff -- Published Research

US Geological Survey

2015

Linking thermodynamic modelling, Lu-Hf geochronology and trace elements in garnet: new $\stackrel{P}{P}-\mathrm{T}-\mathrm{t}$ paths from the Sevier hinterland

A. M. Cruz-Uribe

Northern Arizona University, acruzuribe@whoi.edu

T. D. Hoisch

Northern Arizona University

M.L. Wells

University of Nevada, Las Vegas

J.D. Vervoort

Washington State University

F. K. Mazdab

Stanford University

Follow this and additional works at: http://digitalcommons.unl.edu/usgsstaffpub

Cruz-Uribe, A. M.; Hoisch, T. D.; Wells, M. L.; Vervoort, J. D.; and Mazdab, F. K., "Linking thermodynamic modelling, Lu-Hf geochronology and trace elements in garnet: new P-T-t paths from the Sevier hinterland" (2015). USGS Staff -- Published Research. 859.

http:// digitalcommons.unl.edu/usgsstaffpub/859

This Article is brought to you for free and open access by the US Geological Survey at DigitalCommons@University of Nebraska - Lincoln. It has been accepted for inclusion in USGS Staff -- Published Research by an authorized administrator of DigitalCommons@University of Nebraska - Lincoln. 


\title{
Linking thermodynamic modelling, Lu-Hf geochronology and trace elements in garnet: new $P-T-t$ paths from the Sevier hinterland
}

\author{
A. M. CRUZ-URIBE, ${ }^{1, *}$ T. D. HOISCH, ${ }^{1}$ M. L. WELLS, ${ }^{2}$ J. D. VERVOORT ${ }^{3}$ AND F. K. MAZDAB ${ }^{4}{ }^{\dagger}$ \\ ${ }^{1}$ School of Earth Sciences and Environmental Sustainability, Northern Arizona University, PO Box 4099, Flagstaff, AZ \\ 86011, USA (acruzuribe@whoi.edu) \\ ${ }^{2}$ Department of Geoscience, University of Nevada Las Vegas, 4505 Maryland Parkway, Las Vegas, NV 89154, USA \\ ${ }^{3}$ School of the Environment, Washington State University, Pullman, WA 99164, USA \\ ${ }^{4}$ School of Earth Sciences, Stanford University USGS SHRIMP Lab, Green Earth Sciences Building, 367 Panama Street \\ Room 89, Stanford, CA 94305, USA
}

ABSTRACT Major element, trace element and Lu-Hf geochronological data from amphibolite facies pelitic schist in the Raft River and Albion Mountains of northwest Utah and southern Idaho indicate that garnet grew during increasing pressure, interpreted to be the result of tectonic burial and crustal thickening during Sevier orogenesis. Garnet growth was interrupted by hiatuses interpreted from discontinuities in major element zonation. Pressure-temperature paths were determined from the pre-hiatus portions of the garnet chemical zoning profiles and indicate an increase of $\sim 2 \mathrm{kbar}$ and $\sim 50{ }^{\circ} \mathrm{C}$ in the western Raft River Mountains. Garnet Lu-Hf dates of $150 \pm 1 \mathrm{Ma}$ in the western Raft River Mountains and $138.7 \pm 0.7 \mathrm{Ma}$ and $132 \pm 5 \mathrm{Ma}$ in the southern Albion Mountains indicate the timing of garnet growth. Lutetium garnet zoning profiles indicate that the $\mathrm{Lu}-\mathrm{Hf}$ ages are biased towards the posthiatus or outer pre-hiatus segments, indicating that the determined ages likely post-date the recorded $P-T$ path history or date the tail end of the paths. Crustal thickening associated with Sevier orogenesis in the western Raft River Mountains thus began slightly before $150 \pm 1 \mathrm{Ma}$, in the Late Jurassic. This study shows that integrating $P-T$ paths determined from garnet growth zoning with Lu-Hf garnet geochronology and in situ garnet trace element analyses is an effective approach for interpreting and dating deformation events in orogenic belts.

Key words: garnet Lu-Hf geochronology; petrochronology; $P-T-t$ path; Sevier orogen; trace elements.

\section{INTRODUCTION}

The timing of thrusting within the Sevier orogenic belt of the North American Cordillera has been primarily constrained by cross-cutting relationships and syn-orogenic sedimentary deposits (e.g. Heller et al., 1986; DeCelles, 2004). Amphibolite facies pelitic schists from the Raft River, Albion and Grouse Creek mountains of northwest Utah and southern Idaho provide a unique opportunity to study the tectonic evolution of the Sevier hinterland through garnet geochemistry and geochronology (Harris et al., 2007; Wells et al., 2012; Hoisch et al., 2014). Garnet has been identified as a critical mineral for linking

* Present address: Department of Geology and Geophysics, Woods Hole Oceanographic Institution, 266 Woods Hole Rd, Woods Hole, MA 02543, USA.

${ }^{\dagger}$ Present address: Department of Geosciences, University of Arizona, 1040 E. 4th St., Gould-Simpson Bldg. (Bldg. 77), Tucson, AZ 85721, USA. small-scale petrological processes to large-scale orogenic processes because of its usefulness both as a geochronometer and for recording changes in $P-T$ conditions during its growth. Understanding the trace element zoning and petrological context of minerals used for geochronology has become paramount in interpreting the dates, durations and $P-T-t$ histories of tectonic events (e.g. Anczkiewicz et al., 2007; Lagos et al., 2007; Cheng et al., 2008; Endo et al., 2009; Corrie et al., 2010; Kylander-Clark et al., 2013; Mottram et al., 2014), as evidenced by the increasingly popular use of the term 'petrochronology'.

Documentation of trace element zoning is critical for interpreting garnet geochronology, particularly with respect to $\mathrm{Lu}$ zoning in applications of $\mathrm{Lu}-\mathrm{Hf}$ geochronology. The partitioning of $\mathrm{Lu}$ and other heavy rare earth elements (HREE) during garnet growth may be described as a simple Rayleigh fractionation process (e.g. Hollister, 1966), resulting in HREE profiles that decrease from core to rim (e.g. Lapen et al., 2003; Skora et al., 2006; Anczkie- 
wicz et al., 2007; Kohn, 2009). However, multiple studies have shown that the distribution of $\mathrm{Lu}$ and other rare earth elements (REE) in garnet is not always this straightforward (e.g. Otamendi et al., 2002; Yang \& Rivers, 2002; King et al., 2004; Skora et al., 2006; Kohn, 2009; Moore et al., 2013). Consequently, Rayleigh distribution cannot be assumed for compatible elements such as the middle and heavy REEs in garnet.

Anomalous HREE+Y zoning in garnet has been reported from numerous rock types from a wide variety of tectonic settings (e.g. Otamendi et al., 2002; Yang \& Rivers, 2002; King et al., 2004; Moore et al., 2013) using in situ techniques such as secondary ionization mass spectrometry and laser ablation inductively coupled plasma mass spectrometry (LA-ICPMS). Workers have documented near-rim Lu increases (e.g. Lagos et al., 2007) and HREE+Y annuli in garnet (e.g. Yang \& Rivers, 2002; Moore et al., 2013). Interpretations of these phenomena include: the breakdown of a HREE-phase (e.g. Gieré et al., 2011); open-system behaviour during garnet growth (e.g. Corrie et al., 2010); changes in garnet growth rate and diffusion rates (e.g. Skora et al., 2006; Moore et al., 2013); post-growth-hiatus resorption (e.g. Yang \& Rivers, 2002), and retrograde rim dissolution (Kohn, 2009).

In this study, we present new $P-T$ paths, $\mathrm{Lu}-\mathrm{Hf}$ dates, and in situ trace element zoning for garnet from amphibolite facies pelitic schist from the Raft River-Albion-Grouse Creek metamorphic core complex of the western United States. This study links subtle changes recorded in major element zoning in garnet with more obvious changes in trace element zoning to interpret a reaction history (e.g. KonradSchmolke et al., 2008). We also evaluate the distribution of trace elements in garnet (e.g. Lu) to interpret the significance of $\mathrm{Lu}-\mathrm{Hf}$ garnet dates with respect to the $P-T$ paths derived from garnet from the same rocks. The resultant $P-T-t$ paths provide insight into the timing of early, previously undated tectonic events within the hinterland of the Sevier orogen, and provide a basis for evaluating the relationship between major and trace element zoning and $\mathrm{Lu}-\mathrm{Hf}$ garnet geochronology.

\section{GEOLOGICAL SETTING AND SAMPLE DESCRIPTION}

The Raft River, Albion and Grouse Creek mountains are located in northwest Utah and southern Idaho, within the hinterland of the Late Mesozoic to Early Cenozoic Sevier orogenic belt (Fig. 1). Together they comprise one continuous exposure of amphibolite facies Barrovian metamorphic rocks that were exhumed in the Miocene along flanking low-angle normal faults (Wells et al., 2000; Egger et al., 2003). They belong to a discontinuous north-trending belt with similar exposures of metamorphic rocks in the western United States that have been termed 'Cordilleran metamorphic core complexes' (e.g. Crittenden et al., 1980).

The Raft River-Albion-Grouse Creek metamorphic core complex consists of Archean basement overlain by a tectonically thinned sequence of metasedimentary rocks of Neoproterozoic to Permian age, designated the Raft River Mountains sequence (Compton, 1972; Miller, 1983; Wells, 1997; Wells et al., 1998; Hoisch et al., 2002; Yonkee et al., 2014). The Neoproterozoic schist of Mahogany Peaks, the unit sampled in this study, is located in the footwall of the Basin-Elba fault (Fig. 1), the only major thrust fault preserved in the region (Miller, 1983). The schist of Mahogany Peaks was sampled from two general localities: (i) outcrops $\sim 100 \mathrm{~m}$ apart in the Raft River Mountains (LHRR10D, LHRR10I); and (ii) outcrops $\sim 3 \mathrm{~km}$ apart in the Albion Mountains (THAL4E, THAL6B) (Fig. 1). Previous work has yielded $P-T$ paths from the two Albion Mountains samples (THAL4E and THAL6B), which record an overall pressure increase of $\sim 3 \mathrm{kbar}$ (Harris et al., 2007).

The Raft River Mountains samples LHRR10D and LHRR10I contain quartz, muscovite, biotite, staurolite and garnet. Porphyroblastic garnet (up to $4 \mathrm{~mm})$ and staurolite $(\sim 3-12 \mathrm{~mm})$ are subidioblastic. Biotite is also porphyroblastic and up to $5 \mathrm{~mm}$ in size. Garnet and some staurolite grains have quartz inclusions concentrated in their cores and have relatively inclusion-free rims. Minor chloritization of some garnet and staurolite grains is also present. The fine-grained matrix (LHRR10D: $\sim 100-500 \mu \mathrm{m}$; LHRR10I: $\sim 50-300 \mu \mathrm{m}$ ) is composed primarily of quartz and muscovite. Apatite, xenotime and allanite are present in the matrix and as inclusions in garnet, staurolite and biotite. Small grains of graphite occur in the matrix. Minor deformation is indicated by the undulose extinction of quartz and weakly developed strain shadows around garnet and staurolite.

Samples LHRR10D and LHRR10I are classed as high-alumina pelitic schists, in which biotite is a late crystallizing phase relative to garnet. Garnet growth is interpreted from major element zoning to have occurred through two distinct reactions, separated by a reaction period in which garnet was partially consumed. Petrographically, the only evidence of a complex garnet growth history is a concentric birefringence zoning pattern observed in some staurolite grains in sample LHRR10D that is truncated by adjacent garnet, suggesting that staurolite was consumed as garnet grew. We interpret that this occurred during the earliest stage of retrogradation, which partially reversed the reaction that brought biotite into the assemblage (approximately garnet + chlorite $=$ staurolite + biotite) .

Detailed descriptions of samples THAL4E and THAL6B are reported in Harris et al. (2007). Like LHRR10D and LHRR10I, both samples are highalumina pelitic schist. THAL4E contains garnet, staurolite, muscovite, paragonite, quartz and kyanite 
Fig. 1. Generalized geological map of the Raft River-Albion-Grouse Creek metamorphic core complex, showing approximate sample locations for samples LHRR10I, LHRR10D, THAL4E and THAL6B. Upper right inset shows the leading edge of the Sevier thrust belt (thick barbed line) and metamorphic core complexes in the hinterland of the Sevier belt (solid black). Modified from Harris et al. (2007).

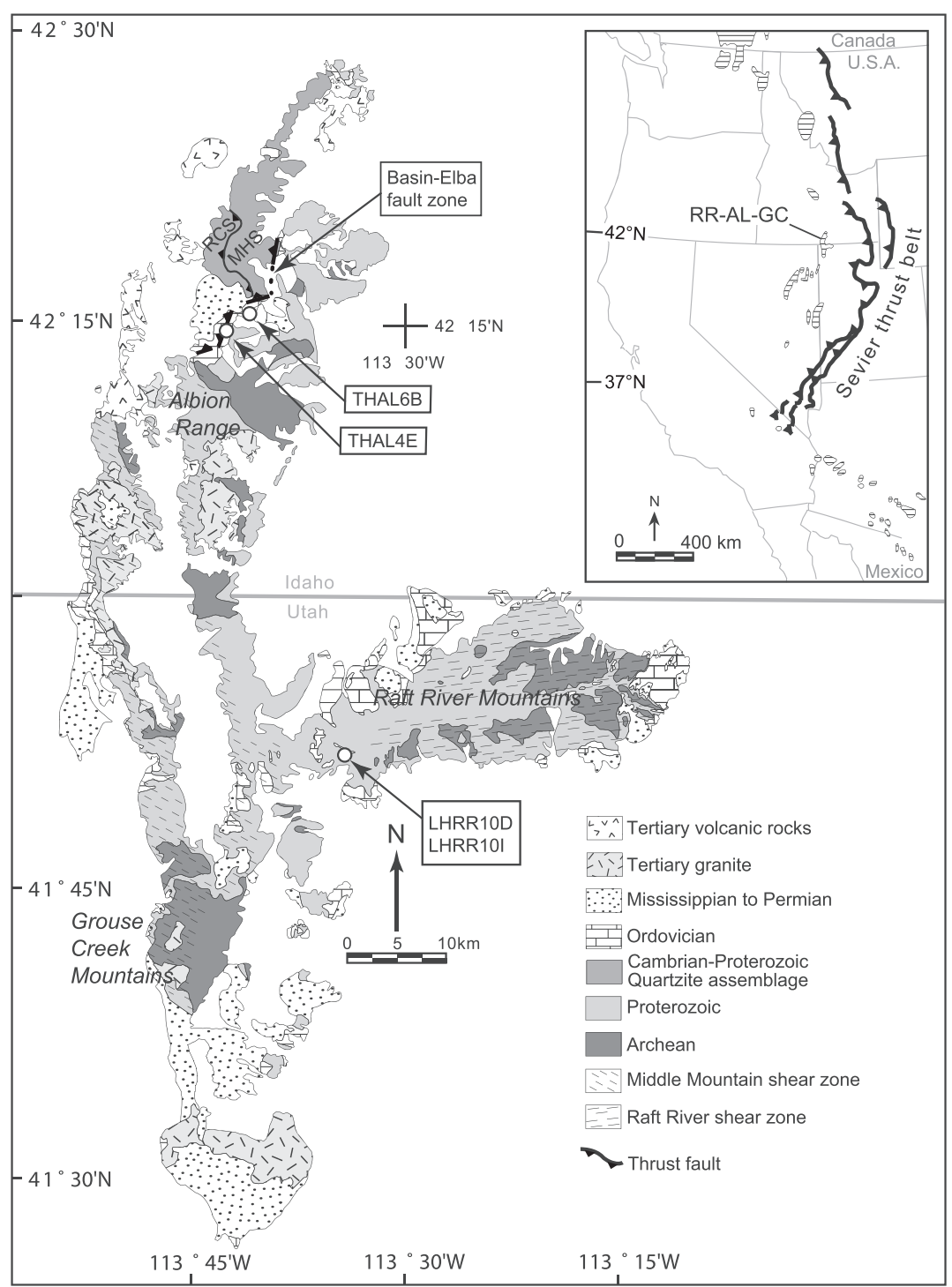

and THAL6B contains garnet, staurolite, muscovite, biotite, paragonite, plagioclase and quartz. Accessory phases in both samples include graphite, ilmenite, apatite and rutile. Garnet from these samples shares a similar reaction history as described above for THRR10D and THRR10I, with a growth hiatus preserved in the garnet profile.

\section{MINERAL CHEMISTRY}

\section{Major element geochemistry}

Major element maps of garnet (Mg, Fe, Mn and $\mathrm{Ca}$; Fig. 2) were produced using an Oxford Instruments Energy Dispersive System attached to the JSM6480LV Scanning Electron Microscope at Northern Arizona University. Trace element maps (Y and Ti) were acquired using the electron microprobe in Washington State University's Geoanalytical Lab. Loca- tions for microprobe traverses across garnet were chosen based on the major element maps (Fig. 2) to pass through the centre of the garnet concentric zoning, avoid inclusions and capture as much of the rim as possible. Spot analyses of garnet along line traverses and of matrix minerals were acquired using the Cameca MBX electron microprobe at Northern Arizona University using an accelerating voltage of $15 \mathrm{kV}$ (Appendix S1). For garnet traverses, a spot size of $1 \mu \mathrm{m}$ was used. A spot size of $5 \mu \mathrm{m}$ was used to collect matrix mineral compositions. Points along garnet line traverses were spaced $\sim 20 \mu \mathrm{m}$ apart. Major element traverses across garnet from samples LHRR10D and LHRR10I are shown in Fig. 3.

\section{Trace element geochemistry}

Trace elements were analysed along linear traverses in one garnet grain from each sample dated by 


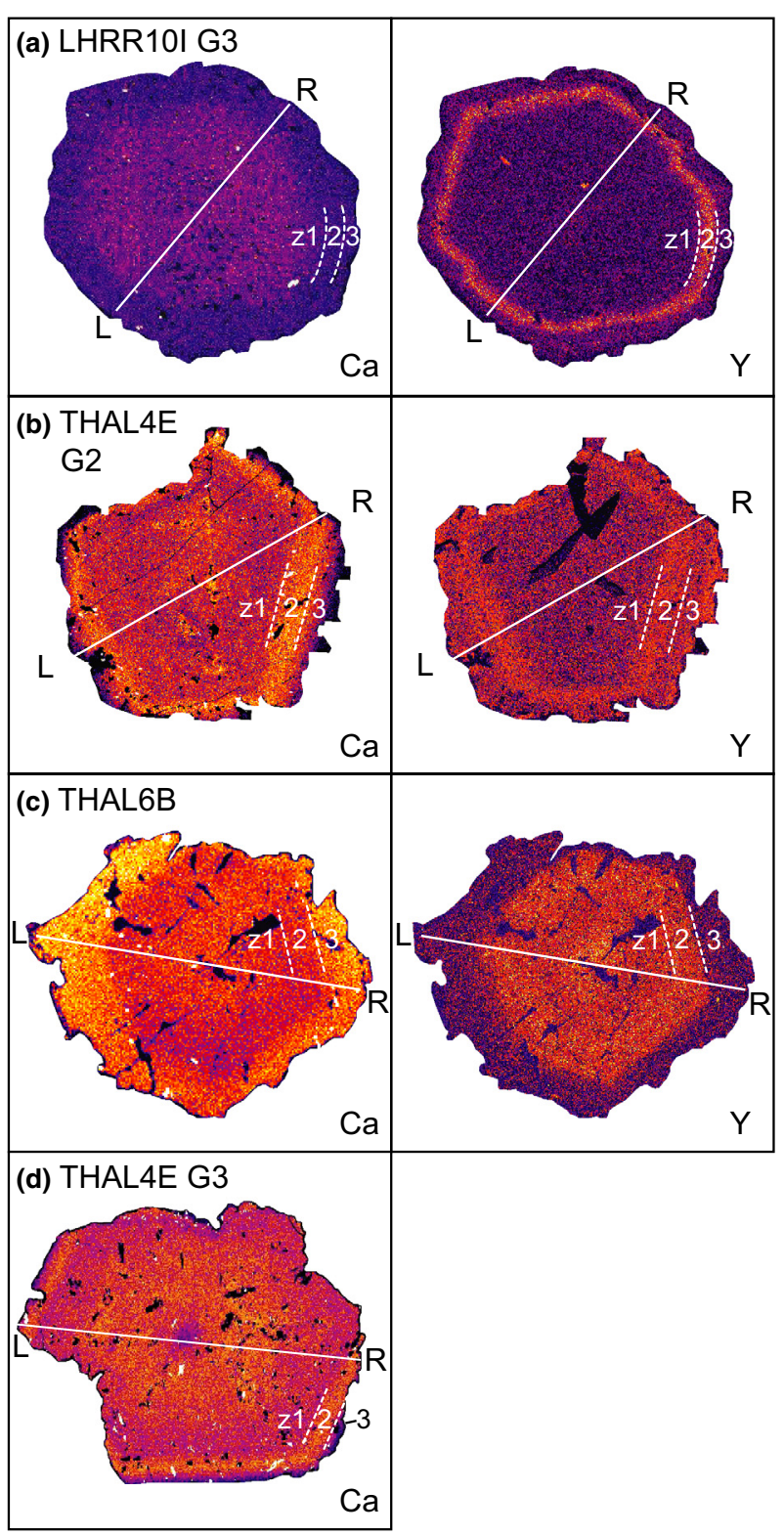

Fig. 2. SEM element maps for $\mathrm{Ca}$ and $\mathrm{Y}$ in (a) garnet 3 from sample LHRR10I; (b) garnet 2 from sample THAL4E; (c) garnet from sample THAL6B; (d) garnet 3 from sample THAL4E. Left (L) and right (R) sides of microprobe and SHRIMP/LA-ICPMS traverses are indicated for each grain. Garnet zones 1, 2 and 3 labelled on each garnet (see text for details).

Lu-Hf, using the SHRIMP-RG at Stanford University. The following garnet crystals were analysed: LHRR10I garnet grain 3, THAL6B garnet grain 1 and THAL4E garnet grain 2. SHRIMP-RG analyses followed the procedures outlined by Mazdab (2009). A $1.83 \mathrm{nA}$ primary $\mathrm{O}_{2}{ }^{-}$ion beam resulting in a spot diameter of $\sim 15 \mu \mathrm{m}$ was used. Approximately 30 points were analysed across each garnet grain, chosen to correspond roughly to the locations of microprobe line traverses from which garnet $P-T$ paths were generated in this and previous studies (Harris et al., 2007). Each analysis was acquired over 535 s. The following isotopes were analysed: ${ }^{30} \mathrm{Si},{ }_{139}^{139} \mathrm{La},{ }^{140} \mathrm{Ce}$, ${ }^{146} \mathrm{Nd},{ }^{4}{ }^{47} \mathrm{Sm},{ }^{153} \mathrm{Eu},{ }^{157} \mathrm{Gd},{ }^{159} \mathrm{~Tb},{ }^{163} \mathrm{Dy},{ }^{165} \mathrm{Ho}$, ${ }^{166} \mathrm{Er},{ }^{169} \mathrm{Tm},{ }^{172} \mathrm{Yb}$ and ${ }^{175} \mathrm{Lu}$. Concentrations were determined relative to the in-house garnet reference material Garnet28, using ${ }^{30} \mathrm{Si}$ as a normalizing mass. Two sigma errors for $\mathrm{Lu}$ analyses are $\sim 10 \%$, based on a $95 \%$ confidence interval of the counting statistics for $\mathrm{Lu}, 2 \sigma$ variability in analyses of the reference material, and assuming 2\% error from microprobe values of the $\mathrm{Si}$ concentration in garnet. Typical $2 \sigma$ errors for other elements range from 5 to $10 \%$, depending on the concentration of the element. Representative acquisition parameters for SHRIMP-RG analyses can be found in Appendix S2.

A second trace element traverse was performed on garnet grain 3 from sample THAL4E using LA-ICPMS at The Pennsylvania State University, using a spot size of $65 \mu \mathrm{m}$, a beam energy density of $\sim 11 \mathrm{~J} \mathrm{~cm}^{-2}$ and a repetition rate of $10 \mathrm{~Hz}$. Each analysis was acquired over $160 \mathrm{~s}$, which consisted of $30 \mathrm{~s}$ of background collection during laser warm-up, $60 \mathrm{~s}$ of dwell time during ablation and $60 \mathrm{~s}$ of washout. The following isotopes were analysed: ${ }^{43} \mathrm{Ca}$, ${ }^{139} \mathrm{La},{ }^{140} \mathrm{Ce},{ }^{146} \mathrm{Nd},{ }^{147} \mathrm{Sm},{ }^{153} \mathrm{Eu},{ }^{157} \mathrm{Gd},{ }^{159} \mathrm{~Tb}$, ${ }^{163} \mathrm{Dy},{ }^{165} \mathrm{Ho},{ }^{166} \mathrm{Er},{ }^{169} \mathrm{Tm},{ }^{172} \mathrm{Yb}$ and ${ }^{175} \mathrm{Lu}$. Trace element concentrations were determined relative to the glass reference material NIST SRM612, using ${ }^{43} \mathrm{Ca}$ as a normalizing mass. Average $2 \sigma$ errors for individual $\mathrm{Lu}$ analyses are $6 \%$; average $2 \sigma$ errors for $\mathrm{Yb}$ analyses are $5 \%$.

Zoning profiles for trace elements are plotted in Figs 4-6 and S1. Trace element data were collected in each garnet along the same traverse used to collect major element data. $P-T$ paths were produced from the major element data in this study (as described below) and in the study of Harris et al. (2007).

\section{Raft River Mountains sample LHRR10I}

Trace element concentrations in garnet 3 from sample LHRR10I are shown in Fig. 4. The core (zone 1) of garnet 3 has high HREE $+Y$ concentrations that decrease towards the rim, consistent with Rayleightype behaviour (e.g. Hollister, 1966). A near-rim annulus in HREE+Y (zone 2), visible in the $\mathrm{Y}$ element map (Fig. 2) and the Lu and $\mathrm{Y}$ zoning profiles (Fig. 4a,b), occurs towards the garnet rim and coincides with the beginning of post-hiatus garnet growth, as identified in the major element zoning (Figs $3 \& 4 c$ ).

\section{Albion Mountains samples THAL4E, THAL6B}

Rare earth element and $\mathrm{Y}$ zoning profiles for garnet grain 2 from sample THAL4E (Fig. S1) are symmetrical with relatively flat cores and near-rim peaks 

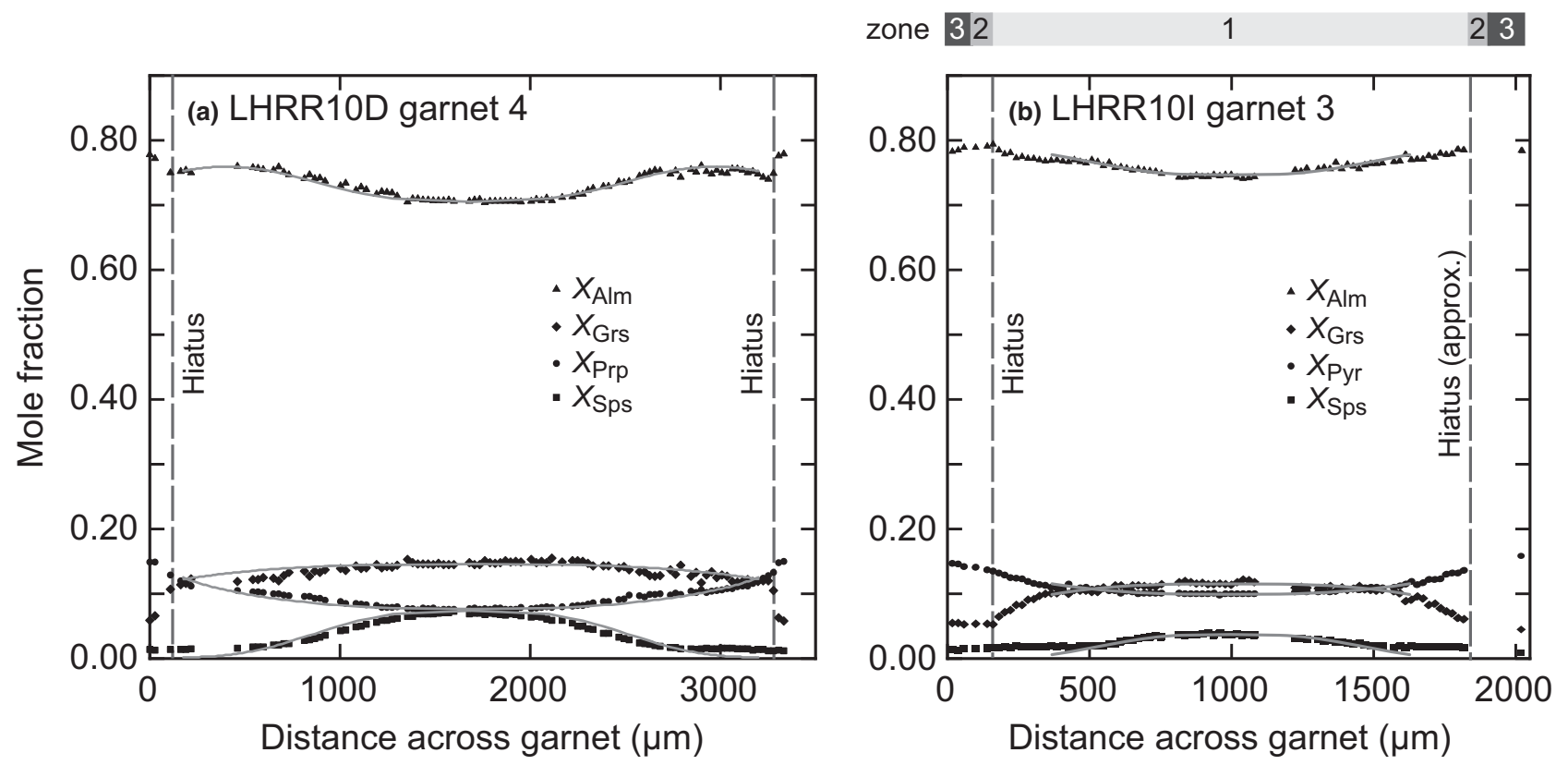

Fig. 3. Microprobe traverse data (symbols) (Appendix S1) and garnet growth simulations (grey lines). Inferred growth hiatuses are shown as dashed lines. (a) Garnet 4 from sample LHRR10D. (b) Garnet 3 from sample LHRR10I. Garnet zones 1, 2 and 3 labelled for reference for LHRR10I. X is mole fraction; Alm, almandine; Grs, grossular; Prp, pyrope; Sps: spessartine.

which, as in sample LHRR10I, coincide with a previously interpreted garnet growth hiatus that was identified in the major element zoning profiles (Harris et al., 2007). This zoning profile does not appear to be the result of simple Rayleigh fractionation that is expected for compatible trace elements in garnet, which would yield HREE+Y profiles that decrease from core to rim (e.g. Lapen et al., 2003; Skora et al., 2006; Anczkiewicz et al., 2007; Kohn, 2009). It is possible that HREE+Y in this rock were fractionated as expected from the onset of garnet growth, but the initial stages of fractionation were not recorded in garnet grain 2 .

The hypothesis that garnet grain 2 does not record the initial stage of garnet growth in the rock is supported by the composite $P-T$ path constructed by Harris et al. (2007) from three garnet profiles within the same thin section. The composite $P-T$ path indicates that garnet grain 2 records only the latest segment of garnet growth, based on the correlation of $X_{\text {Sps }}$ values. To test the validity of this hypothesis, a trace element traverse was performed using LA-ICPMS across garnet grain 3 from sample THAL4E (Fig. 5). Garnet grain 3 records the first segment of garnet growth documented in the composite $P-T$ path of Harris et al. (2007). The trace element traverse for garnet grain 3 shows $\mathrm{HREE}+\mathrm{Y}$ decreasing from the garnet core to the growth hiatus as expected (Fig. 5a,b, zone 1), and a peak in HREE+Y at the onset of rim growth (zone 2), similar to that observed in LHRR10I.

Garnet grain 1 from sample THAL6B reveals high concentrations of $\mathrm{HREE}+\mathrm{Y}$ in the core of the garnet
(Fig. 6; zone 1), which are interpreted to be the result of Rayleigh fractionation. A secondary annulus in HREE+Y occurs towards the rim of the garnet (zone 2) and corresponds very closely with the end of segment 1 and beginning of segment 2 of the garnet growth simulation of Harris et al. (2007).

\section{DETERMINATION OF P-T PATHS}

Thermodynamic modelling to determine $P-T$ paths was undertaken in the model system $\mathrm{Na}_{2} \mathrm{O}-\mathrm{K}_{2} \mathrm{O}$ $\mathrm{CaO}-\mathrm{MgO}-\mathrm{FeO}-\mathrm{MnO}-\mathrm{Al}_{2} \mathrm{O}_{3}-\mathrm{SiO}_{2}-\mathrm{H}_{2} \mathrm{O}$. Excess $\mathrm{H}_{2} \mathrm{O}$ was added, and all $\mathrm{Fe}$ was assumed to be $\mathrm{Fe}^{2+}$. In this study, a modified version of the procedure used in Harris et al. (2007) was used to calculate $P-T$ paths for two new samples, LHRR10D and LHRR10I, the primary difference being the way in which the initial conditions were estimated. The initial conditions were determined using the programs Theriak and Domino (de Capitani \& Petrakakis, 2010; Figs 7 \& 8), whereas a complex iterative procedure was used in Harris et al. (2007). See Appendix $\mathrm{S} 3$ for a detailed explanation of the methods used in the present study. Mineral abbreviations follow Whitney \& Evans (2010).

The $P-T$ paths were calculated using the Gibbs' method based on Duhem's theorem (e.g. Spear, 1995). Inputs for the calculation include the initial conditions corresponding to the beginning of garnet growth (the initial mineral assemblage, mineral modes and compositions, and the $P-T$ of garnet nucleation), and values for the changes in two monitor parameters that occurred during garnet growth. 


\section{LHRR10I}
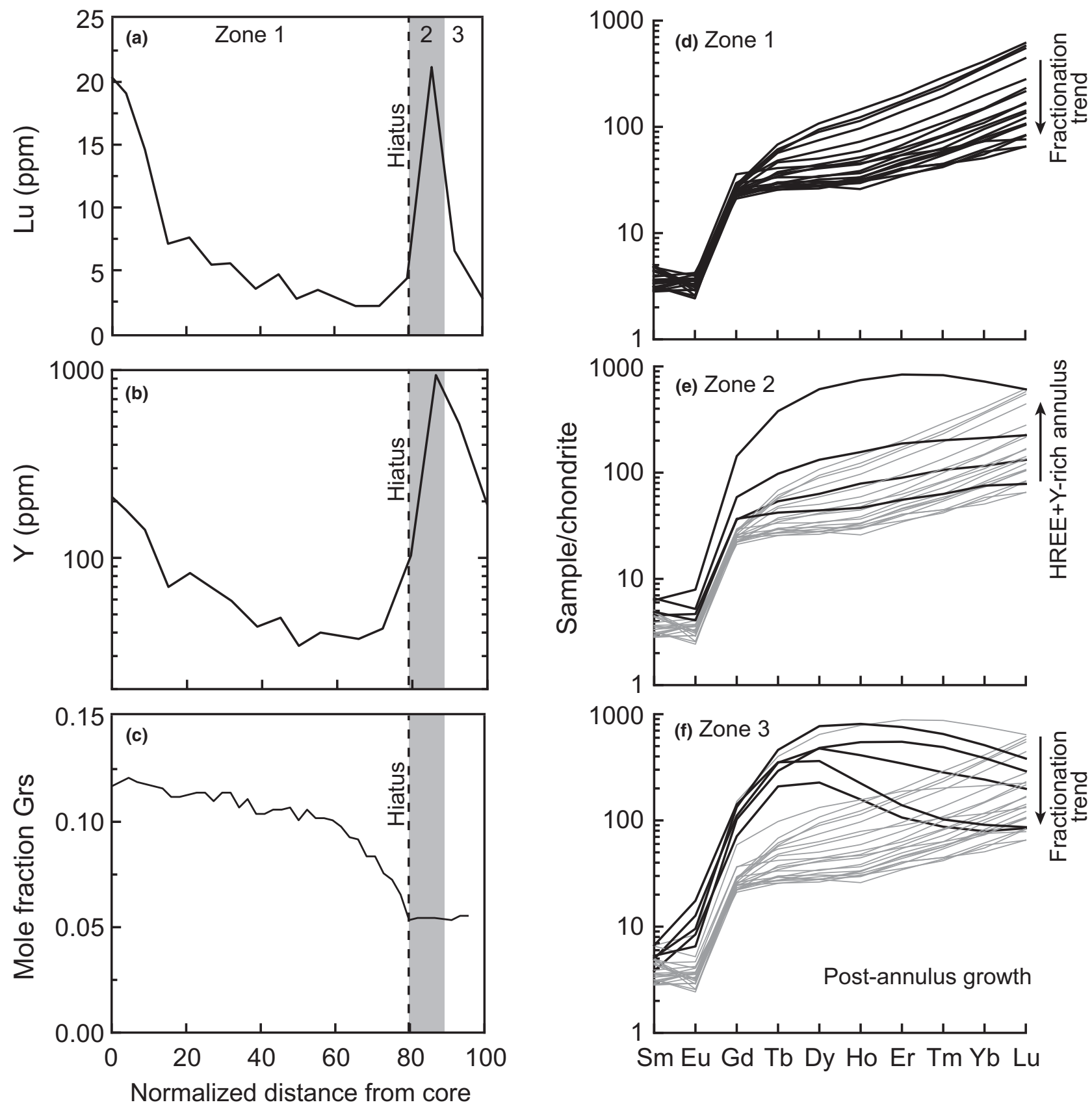

Fig. 4. Trace element zoning in sample LHRR10I garnet 3. Garnet zones based on changes in REE patterns (d-f) are labelled zones 1, 2 and 3 in (a-c). Yttrium+REE-rich annulus marked by grey shaded field (zone 2). (a) Lu concentration (ppm) from core to rim; (b) Y concentration (ppm) from core to rim; (c) Grossular (Grs) content; (d) REE patterns in Zone 1; (e) REE patterns in Zone 2 (Zone 1 shown in light grey); (f) REE patterns in Zone 3 (Zones 1 \& 2 shown in light grey). The growth hiatus interpreted from the major element zoning is indicated by the dashed line and coincides with the beginning of the HREE $+\mathrm{Y}$ annulus (zone 2 ).

The $P-T$ paths for samples THAL4E and THAL6B were previously calculated and reported in Harris et al. (2007). The $P-T$ paths were calculated using the program GIBBS (version dated 16 February 2010; Spear et al., 1991). Major element profiles for garnet were simulated from the core outward assuming fractional crystallization. Changes in the mole fraction of grossular content $\left(\Delta X_{\mathrm{Grs}}\right)$ and the moles of garnet grown $\left(\Delta M_{\mathrm{Grt}}\right)$ were used as monitor parameters for garnet growth. Grossular content was used as a monitor parameter in preference to $X_{\mathrm{Alm}}$, $X_{\mathrm{Sps}}$ or $X_{\mathrm{Prp}}$ because of the relative resistance of $\mathrm{Ca}$ 
THAL4E-G3
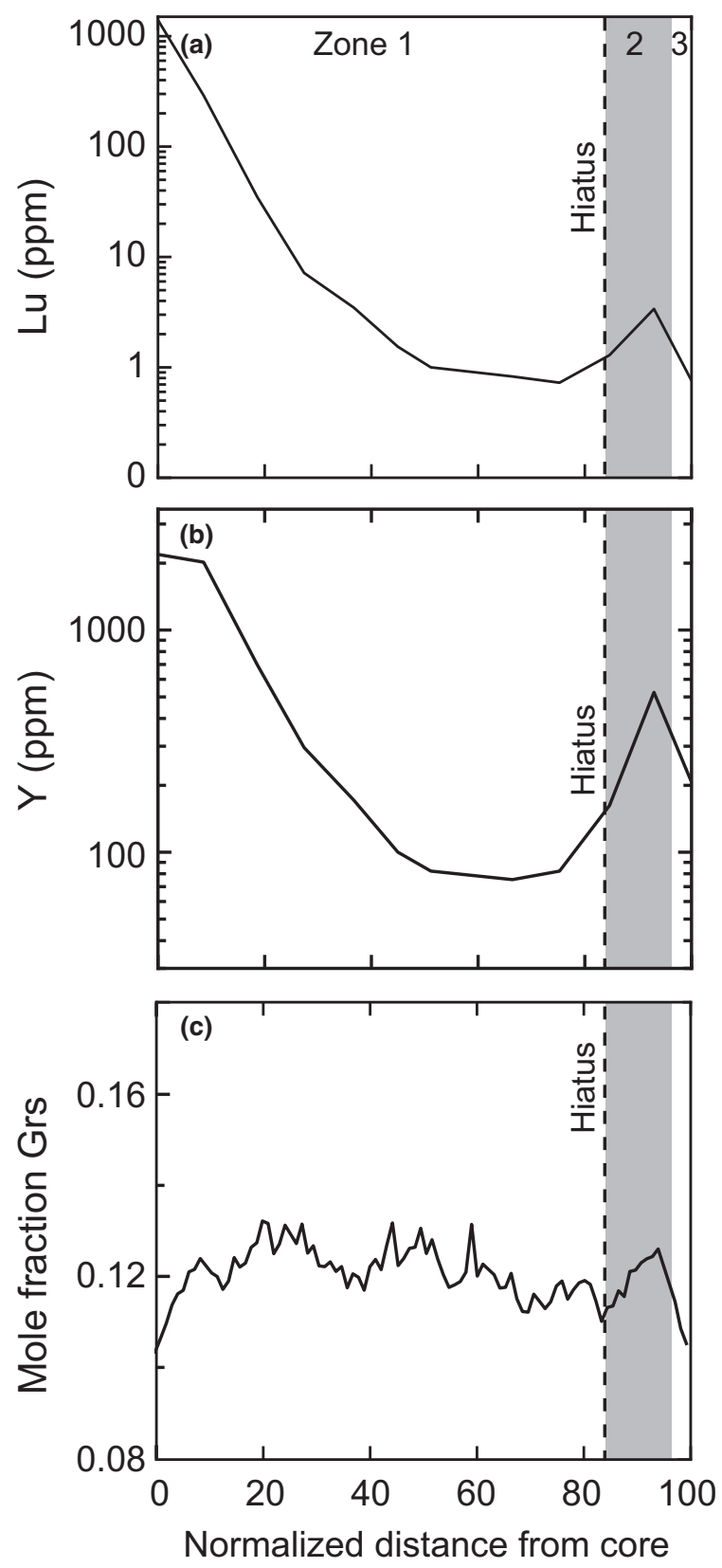
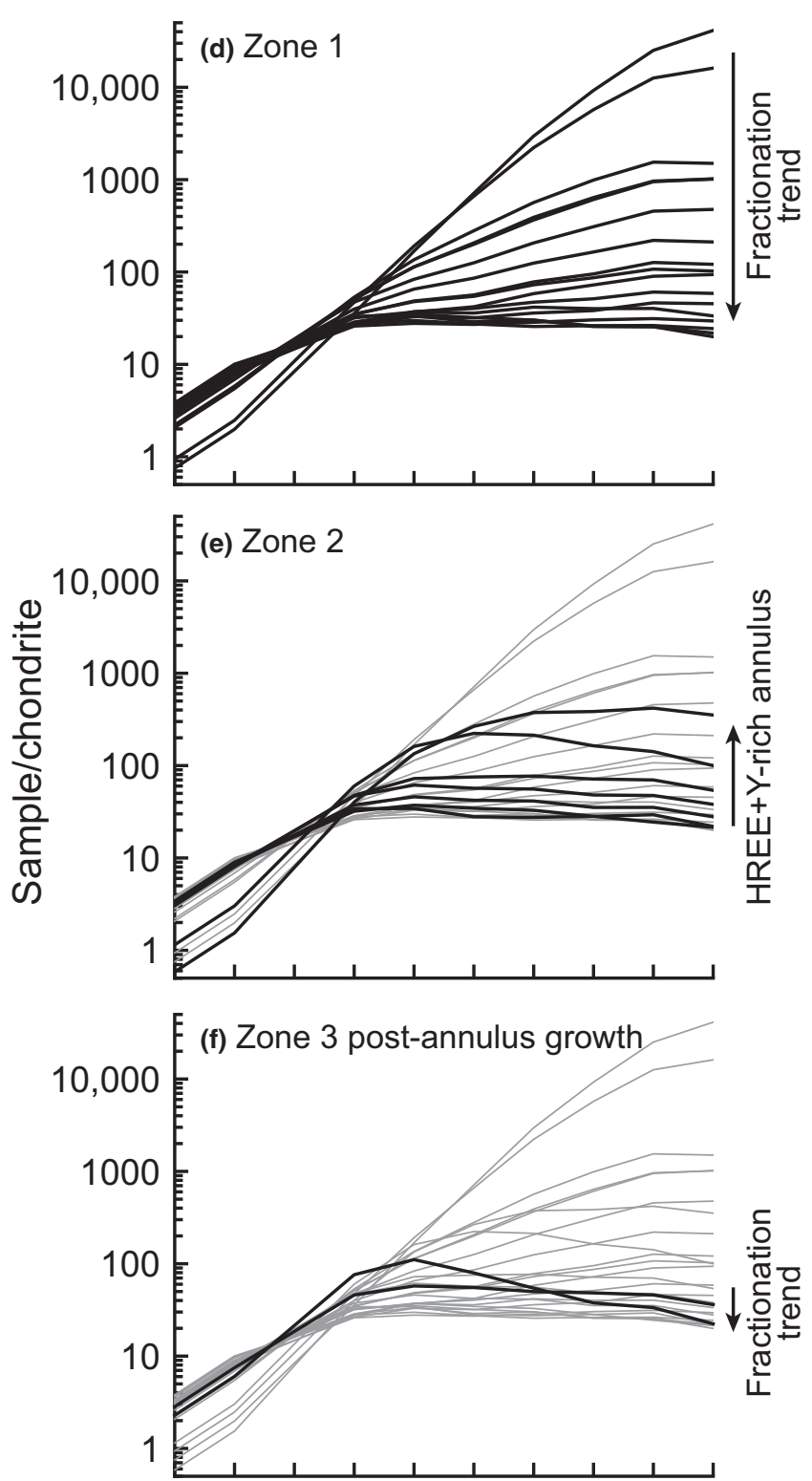

Sm Eu Gd Tb Dy Ho Er Tm Yb Lu

Fig. 5. Trace element zoning in sample THAL4E garnet 3. Garnet zones based on changes in REE patterns (d-f) are labelled zones 1, 2 and 3 in $(\mathrm{a}-\mathrm{c})$. Yttrium+REE-rich annulus marked by grey shaded field (zone 2). (a) Lu concentration (ppm) from core to rim; (b) Y concentration (ppm) from core to rim; (c) Grossular (Grs) content; (d) REE patterns in Zone 1; (e) REE patterns in Zone 2 (Zone 1 shown in light grey); (f) REE patterns in Zone 3 (Zones 1 \& 2 shown in light grey). The growth hiatus interpreted from the major element zoning (Harris et al., 2007) is indicated by the dashed line and coincides with the beginning of the HREE+Y annulus (zone 2).

to diffusional modification after garnet growth compared to Fe, Mn and Mg (Spear, 1995).

\section{$P-T$ path for LHRR10D}

Garnet growth in sample LHRR10D was simulated from the core to a hiatus in the profile that was identified by a pronounced discontinuity in the major element profile (Fig. 3a) (e.g. Spear, 1988; KonradSchmolke et al., 2008; Caddick et al., 2010). We interpret the isochemical plot and garnet core compositional isopleths to indicate that the garnet core grew inside the assemblage quartz + chlorite + muscovite + staurolite + plagioclase (diagonal line fill in Fig. 7b). 
THAL6B
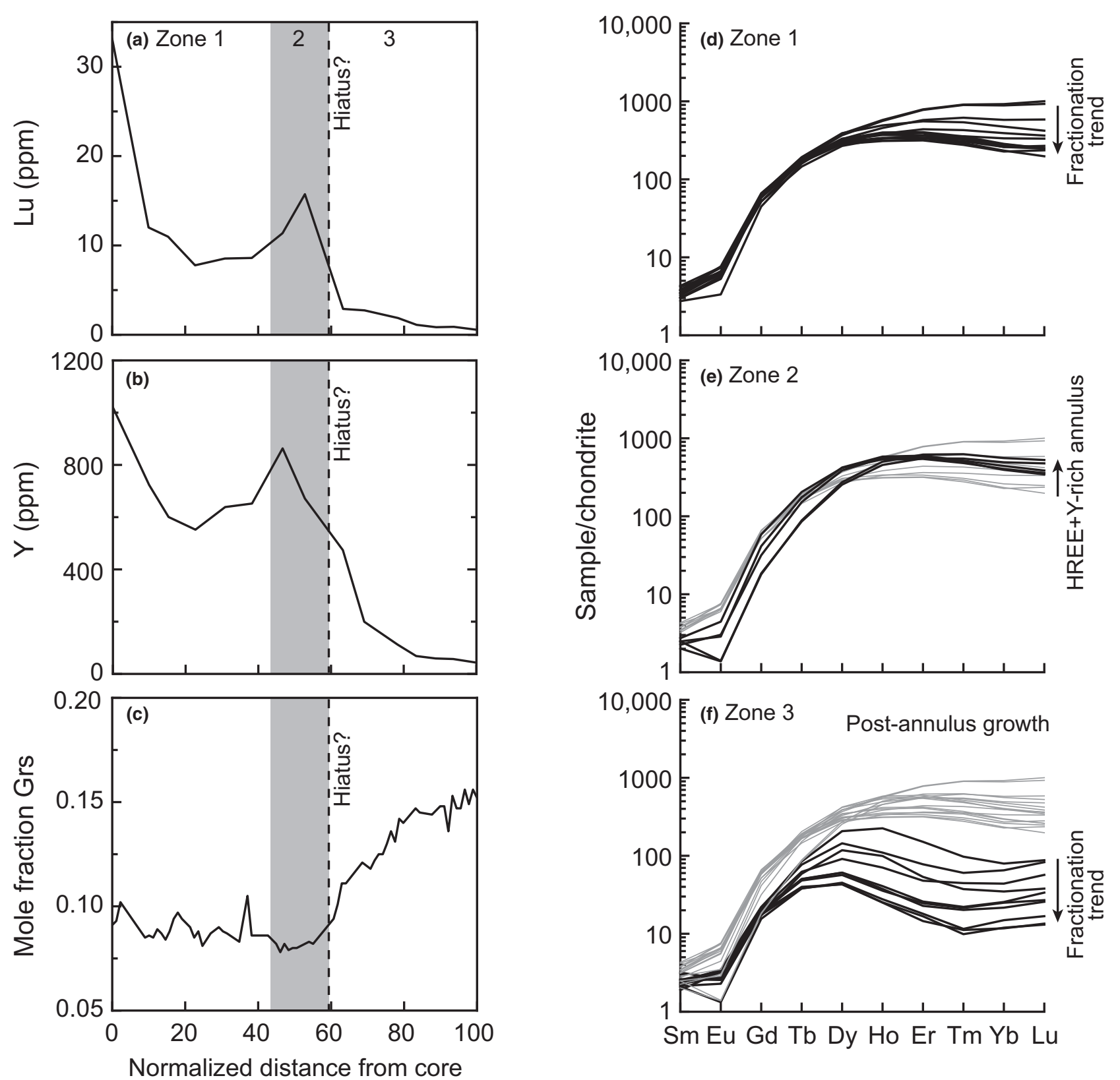

Fig. 6. Trace element zoning in sample THAL6B garnet 2. Garnet zones based on changes in REE patterns (d-f) are labelled zones 1, 2 and 3 in (a-c). Yttrium+REE-rich annulus marked by grey shaded field (zone 2). (a) Lu concentration (ppm) from core to rim; (b) Y concentration (ppm) from core to rim; (c) Grossular (Grs) content; (d) REE patterns in Zone 1; (e) REE patterns in Zone 2 (Zone 1 shown in light grey); (f) REE patterns in Zone 3 (Zones 1 \& 2 shown in light grey).

Garnet core growth took place by the breakdown of chlorite via the approximate reaction:

$$
\begin{aligned}
& \text { quartz }+ \text { plagioclase }+ \text { chlorite }+ \text { muscovite } \\
& =\text { garnet }+ \text { biotite }+\mathrm{H}_{2} \mathrm{O}
\end{aligned}
$$

The garnet growth simulation yielded a $P-T$ path consisting of a temperature increase of $37^{\circ} \mathrm{C}$ and pressure increase of $1.1 \mathrm{kbar}$ (Fig. 7b; Table 1), and points in the direction of the final mineral assemblage field of quartz + muscovite + biotite + staurolite + chlorite + garnet (diagonal line fill in Fig. 7d). Crossing this field with increasing temperature yielded partial garnet consumption via the approximate reaction:

$$
\begin{aligned}
& \text { garnet }+ \text { muscovite }+ \text { chlorite } \\
& =\text { staurolite }+ \text { biotite }+\mathrm{H}_{2} \mathrm{O}
\end{aligned}
$$


The garnet growth simulation is a close match to the analytical data (Fig. 3a). A resumption of garnet growth created the observed hiatus and discontinuity in the garnet profile. The conditions of growth for the post-hiatus segment are constrained by the intersection of garnet compositional isopleths (grey fields in Fig. 7d) and by the final mineral assemblage of the rock (diagonal line fill in Fig. 7d). We interpret that the peak temperature occurred inside the final mineral assemblage field and that post-hiatus garnet growth occurred when a partial reversal of the garnet consumption reaction took place during cooling.

\section{$P-T$ path for LHRR10I}

The growth of garnet in sample LHRR10I was similar to LHRR10D. Both have the same initial and final assemblages, and a similar hiatus is interpreted from a discontinuity in the profile (Fig. 3b). One difference is that the pre-hiatus portion of the profile is interpreted to reflect growth in two different mineral assemblages rather than one; the central core grew in the presence of plagioclase similar to LHRR10D, while the outer core, identified as the portion outboard of the break in Ca-slope, grew in the absence of plagioclase. Growth of the outer core portion could not be simulated due to the absence of a Ca-source in the model system. The outer core portion, which incorporates some $\mathrm{Ca}$, grew within the mineral assemblage quartz + chlorite + muscovite + staurolite. The models used for these minerals do not include $\mathrm{Ca}$ (see Appendix S3). We interpret the sharp drop in $\mathrm{Ca}$ through the outer core portion of the profile to reflect growth following the loss of plagioclase from the assemblage. Consequently, only the central core portion could be simulated using the Gibbs' method.

The garnet growth simulation for the central core portion of LHRR10I yielded a $P-T$ path consisting of a temperature increase of $12.7^{\circ} \mathrm{C}$ and a pressure increase of 93 bar (Fig. 8b). The garnet growth simulation is a close match to the analytical data (Fig. 3). As the central core grew, plagioclase was fully consumed. Similar to LHRR10D, the final mineral assemblage and post-hiatus garnet isopleths constrain the post-hiatus segment to a narrow field in $P-T$ space (diagonal line pattern, Fig. $8 d$ ). We interpret the hiatus in the same way as for LHRR10D; garnet is partially consumed as the final mineral assemblage field is crossed with increasing temperature, and then partially regrown as the garnet consumption reaction is reversed during cooling. For both LHRR10I and LHRR10D, the fact that chlorite occurs only as rims on staurolite and garnet suggests that the narrow field representing the final assemblage was completely traversed during progradation, as this would have consumed all matrix chlorite.

\section{LU-HF GEOCHRONOLOGY}

\section{Lu-Hf methods}

Garnet from three samples of the schist of Mahogany Peaks was dated using the Lu-Hf method (e.g. Scherer et al., 2000; Anczkiewicz et al., 2007; Cheng et al., 2008; Corrie et al., 2010; Wells et al., 2012): sample LHRR10I from the Raft River Mountains and samples THAL4E and THAL6B from the Albion Mountains. Sample preparation was done using a porcelain mortar and pestle to crush and separate garnet from other minerals in the rock. For each sample, five 200-250 mg separates of relatively inclusion-free garnet were hand-picked using a binocular microscope. Whole-rock isotopic analysis was performed on the bulk rock ( $250 \mathrm{mg} /$ dissolution) from each sample. All samples were crushed to $\sim 30 \mu \mathrm{m}$ size using a diamonite ${ }^{\circledR}$ mortar and pestle, dissolved via hotplate dissolution (garnet separates) or high pressure Teflon bombs (whole-rock separates), and spiked using a mixed ${ }^{176} \mathrm{Lu}-{ }^{180} \mathrm{Hf}$ tracer. Sample-spike equilibration was achieved by hotplate equilibration for $24-48 \mathrm{~h}$ after primary dissolution, as outlined in Vervoort et al. (2004).

$\mathrm{Lu}$ and $\mathrm{Hf}$ were separated using cation-exchange columns as described in Cheng et al. (2008). Isotopic analyses were carried out by MC-ICP-MS (ThermoFinnigan Neptune). Hf solutions were introduced using an Aridus microconcentric desolvating nebulizer (Cetac Inc.) as dry aerosols, resulting in an enhancement of $\mathrm{Hf}$ signals. Hf analyses were normalized to ${ }^{176} \mathrm{Hf} /{ }^{177} \mathrm{Hf}=0.282160$ for the $\mathrm{Hf}$ standard JMC 475 (Vervoort \& Blichert-Toft, 1999). Mass fractionation and isobaric interferences were corrected as outlined in Vervoort et al. (2004). All chemical separations and mass spectrometry were performed at Washington State University.

\section{Lu-Hf results}

Reduced $\mathrm{Lu}-\mathrm{Hf}$ data for all samples are listed in Table 2, and the resulting isochrons are shown in Fig. 9. The $\mathrm{Lu}-\mathrm{Hf}$ dates were calculated with Isoplot (Ludwig, 2003) and using the ${ }^{176} \mathrm{Lu}$ decay constant of $1.867 \times 10^{-11}$ (Scherer et al., 2001; Söderlund et al., 2004). Regression calculations used a $0.5 \% 2 \sigma$ uncertainty for ${ }^{176} \mathrm{Lu} /{ }^{177} \mathrm{Hf}$ and, for ${ }^{176} \mathrm{Hf} /{ }^{177} \mathrm{Hf}$, the $2 \sigma$ inrun uncertainty of each analysis added in quadrature with an external reproducibility of $0.01 \%$. In the isochrons shown in Fig. 9, points shown in grey were not included in date calculations. In addition to these regressions, 'individual garnet fraction' dates were also calculated for each sample. These were calculated using the ${ }^{176} \mathrm{Lu} /{ }^{177} \mathrm{Hf}$ and ${ }^{176} \mathrm{Hf} /{ }^{177} \mathrm{Hf}$ for each garnet fraction combined with the corresponding whole-rock composition for that sample. The purpose of these dates is to characterize the variation in individual data points about the calculated isochron. 
(a) LHRR10D - core

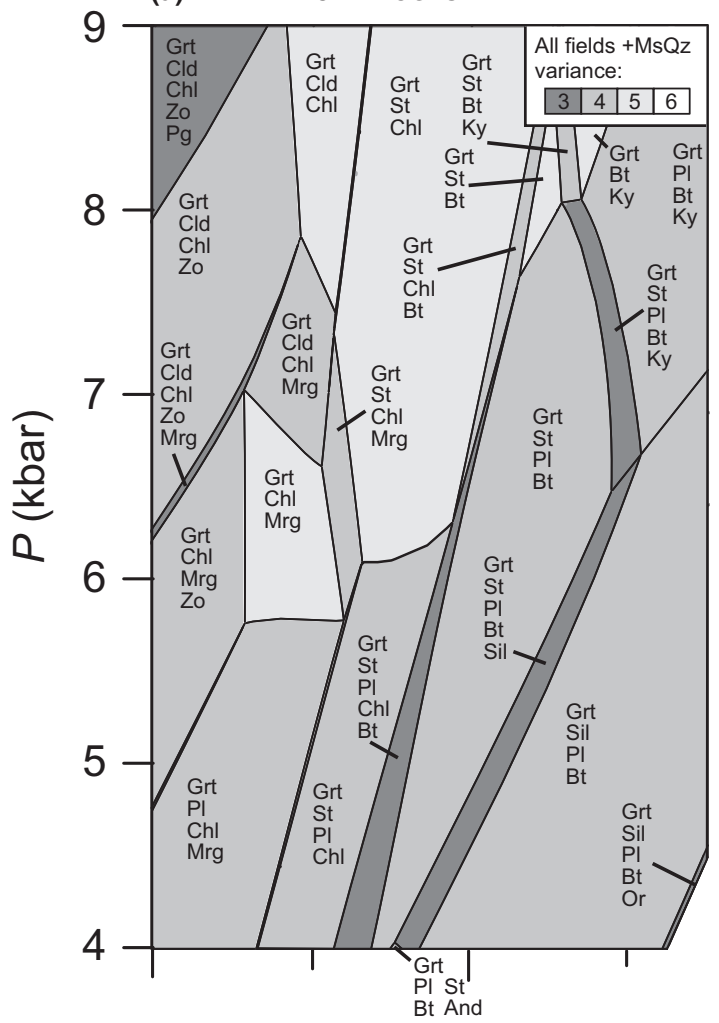

(c) LHRR10D - post-hiatus

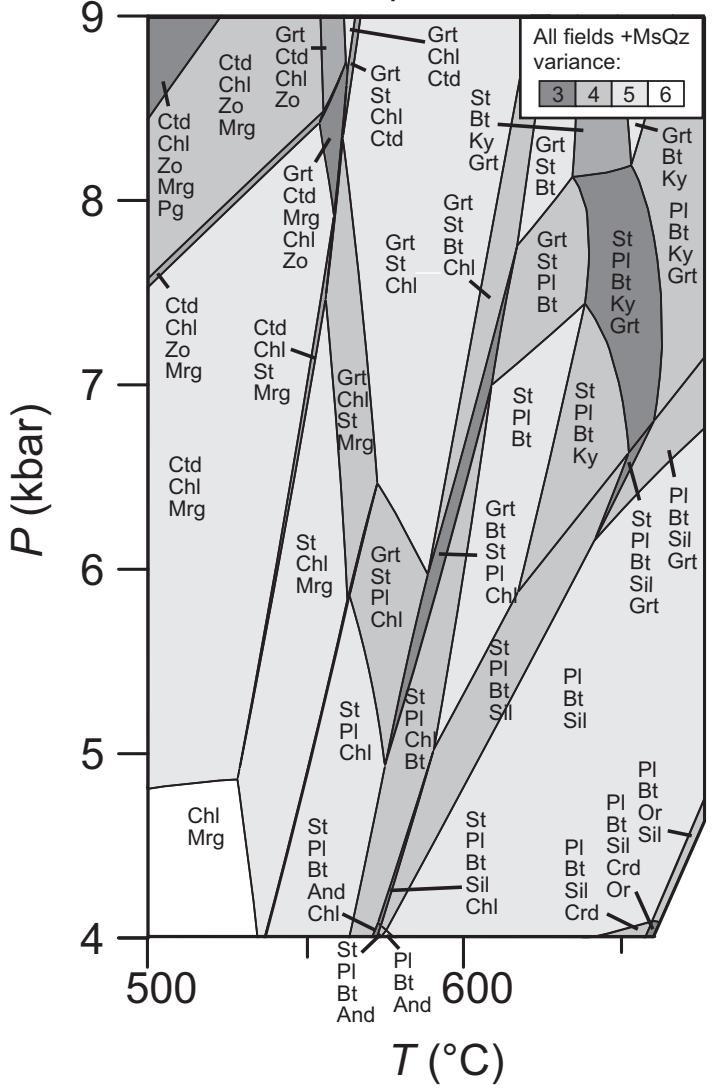

(b) LHRR10D - core

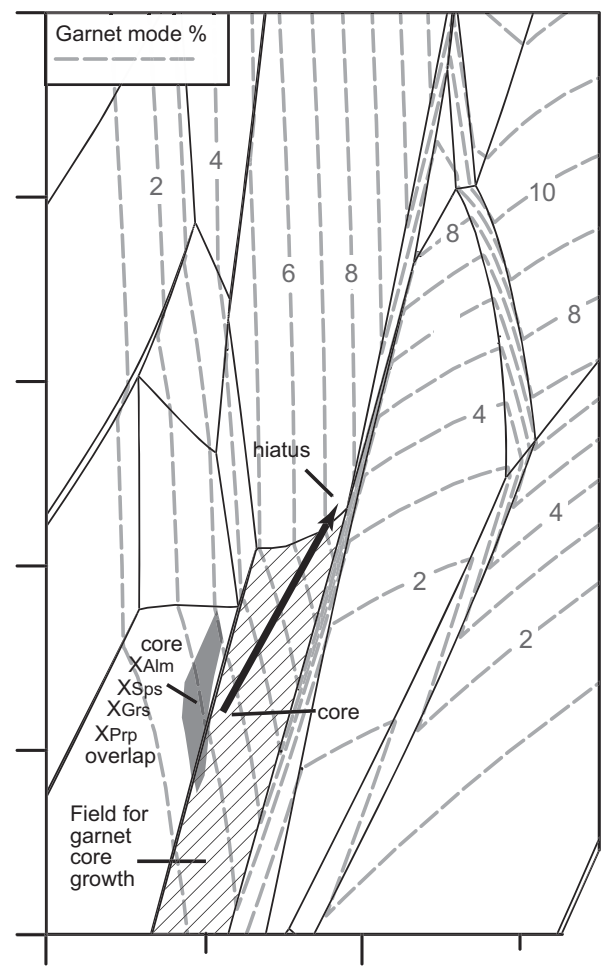

(d) LHRR10D - post-hiatus

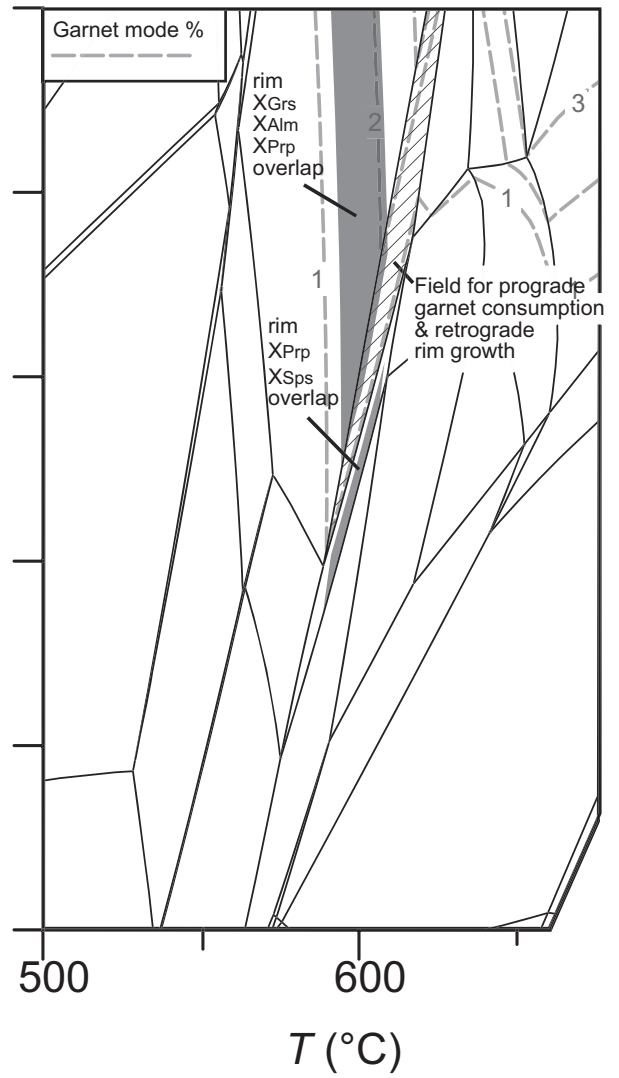


Fig. 7. Results of pseudosection modelling for sample LHRR10D. Plots are shown representing the initiation of garnet growth calculated using the full bulk composition $(\mathrm{a}, \mathrm{b})$ and post-hiatus (rim) growth calculated using bulk compositions adjusted to exclude the pre-hiatus portion of the garnet (c, d) (see Table S1 and Appendix S3 for details of the bulk composition calculations). Garnet mode (\%) contours indicated by dashed lines (b, d). (a) Isochemical plot for pre-hiatus garnet growth with mineral assemblage fields labelled and shaded according to variance. (b) Garnet mode isopleths and calculated $P-T$ path for pre-hiatus garnet growth. The overlap of garnet composition isopleths calculated as fields based on the mole fraction values \pm 0.02 are shown in grey. The mineral assemblage fields for garnet growth are shown with a diagonal line pattern. $P-T$ path (thick black line) is shown for pre-hiatus segments of the garnet profile. (c) Isochemical plot for post-hiatus garnet growth. (d) Garnet mode isopleths for post-hiatus garnet growth with fields labelled as in (b).

Points excluded from the regression calculations (generally because of high isobaric interferences on ${ }^{176} \mathrm{Hf}$ ) were not used to calculate individual garnet fraction dates.

\section{Sample LHRR10I}

Five garnet fractions and one whole rock were analysed from sample LHRR10I. Data from three garnet fractions and one whole rock (Fig. 9a) yield a $\mathrm{Lu}-\mathrm{Hf}$ age of $150 \pm 1 \mathrm{Ma}(2 \sigma, \mathrm{MSWD}=1.1)$. Garnet fraction G4 has a significantly older $\mathrm{Lu}-\mathrm{Hf}$ date and, because of high $\mathrm{Lu}$ interferences, this point was not included in the age calculation. Garnet fraction G2 lies above the isochron, and thus may represent a bias with slightly older garnet cores compared to fractions G1, G3 and G5. This fraction yields an individual garnet-whole rock date of $152 \pm 1 \mathrm{Ma}$, which is slightly older than, but within error of the calculated isochron. Individual garnet fraction dates for garnet fractions G1, G3 and G5 yielded ages of $149 \pm 2 \mathrm{Ma}$, $150 \pm 1 \mathrm{Ma}$ and $149 \pm 2 \mathrm{Ma}$ respectively.

\section{Sample THAL $4 E$}

Six garnet fractions and one whole-rock fraction were analysed from sample THAL4E (Fig. 9b); five of the garnet fractions were used to calculate a $\mathrm{Lu}-\mathrm{Hf}$ isochron date of $138.7 \pm 0.7 \mathrm{Ma}(2 \sigma, \mathrm{MSWD}=1.6)$. Garnet fraction G4 and the whole-rock fraction were excluded from the date regression calculation because of high isobaric $\mathrm{Hf}$ interferences. If these analyses were included in the regression the resultant $\mathrm{Lu}-\mathrm{Hf}$ date would be $138.8 \pm 3.4 \mathrm{Ma}$; therefore, their exclusion does not change the date determined for this sample. Garnet faction GA was used as a whole-rock proxy for two-point isochron ages because of the high isobaric Hf interferences with the whole-rock fraction. Two-point isochrons for garnet fractions $\mathrm{G} 1, \mathrm{G} 2, \mathrm{G} 3, \mathrm{G} 5$ and $\mathrm{GC}$ yielded ages of $140 \pm 2 \mathrm{Ma}, 141 \pm 3 \mathrm{Ma}, 140 \pm 3 \mathrm{Ma}, 144 \pm 4 \mathrm{Ma}$ and $138.7 \pm 0.7$ Ma respectively.

\section{Sample THAL6B}

Five garnet and one whole-rock fractions were analysed from sample THAL6B, yielding a $\mathrm{Lu}-\mathrm{Hf}$ date of $132 \pm 5 \mathrm{Ma}(2 \sigma, \mathrm{MSWD}=9.5)$ based on three garnet fractions and the whole rock (Fig. 9c). Garnet fractions G3 and G4 were excluded from the age calculation to obtain a lower MSWD value; including these analyses yields a date of $130 \pm 12$, which is within error of the more precise date but has a much higher MSWD ( 174). The large error in the date, the high MSWD value and the high interferences on most points for this rock are most likely the result of low Hf concentrations in these garnet grains (53$87 \mathrm{ppb}$ ). Despite these limitations, the calculated date of $132 \pm 5 \mathrm{Ma}$ for this sample is considered here to have meaning in the context of its close spatial proximity to sample THAL4E and similar date. Twopoint isochrons for garnet fractions G1, G2 and G5 yield ages of $131 \pm 1 \mathrm{Ma}, 132 \pm 1 \mathrm{Ma}$ and $133 \pm 1$ Ma respectively.

\section{DISCUSSION}

\section{Interpretation of $\boldsymbol{P}-\boldsymbol{T}-\boldsymbol{t}$ paths and trace element zoning}

In their garnet growth simulation of sample THAL6B garnet 2, Harris et al. (2007) noted that the model fit of the garnet rim was poor, particularly for the Fe profile. Harris et al. (2007) proposed opensystem behaviour with respect to $\mathrm{Fe}$ as a possible explanation for the poor fit of the outer rim of this garnet. The trace element zoning features in garnet 2 from sample THAL6B from the Albion Mountains provide a possible alternative explanation to opensystem behaviour for the problems noted for the garnet growth simulation of Harris et al. (2007). The HREE+Y-rich annulus (Fig. 6) is likely similar in origin to the HREE+Y annulus at the growth hiatus of garnet 2 from sample THAL4E. Given the shared $P-T$ history of the two samples, similar rock bulk compositions, and their close spatial proximity (Harris et al., 2007), the increase in HREE+Y in zone 2 of sample THAL6B may also be explained by partial garnet consumption followed by regrowth. One issue with this interpretation is that the break in slope of the Ca profile in this garnet occurs after the spike in HREE+Y, which is different than the relationship between hiatuses and annuli in garnet from the other two locations.

Annuli like those seen in the HREE+Y profiles of samples from the Raft River (LHRR10I) and Albion (THAL4E) Mountains likely indicate local changes in the REE reservoir around the garnet. These changes, and the presence of hiatuses in garnet growth may be 


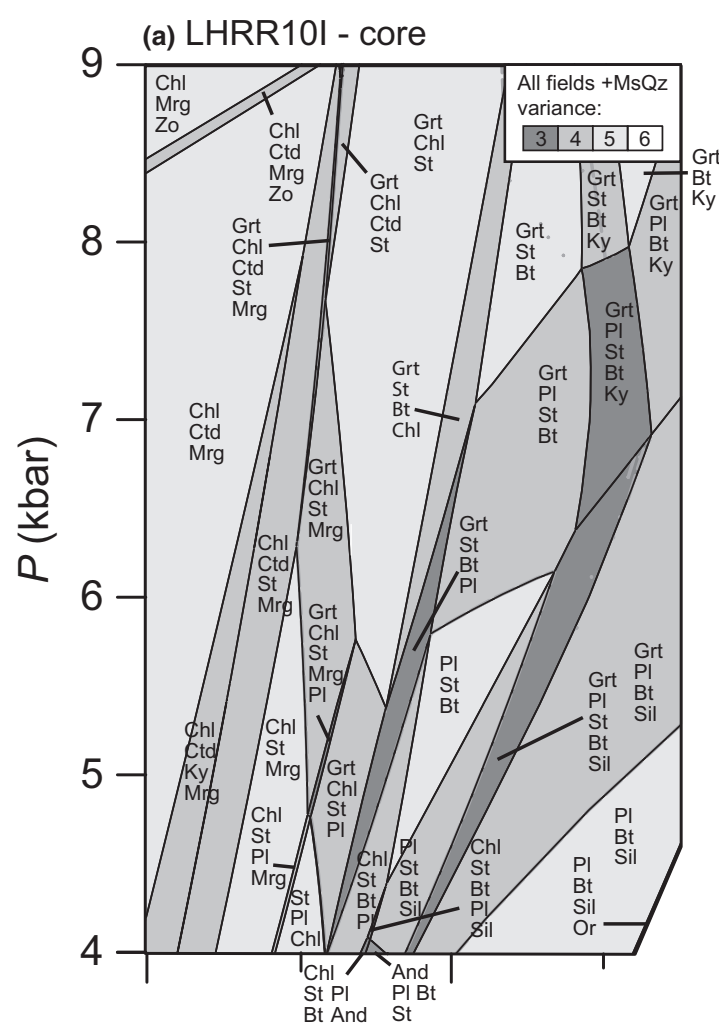

(b) LHRR10I - core
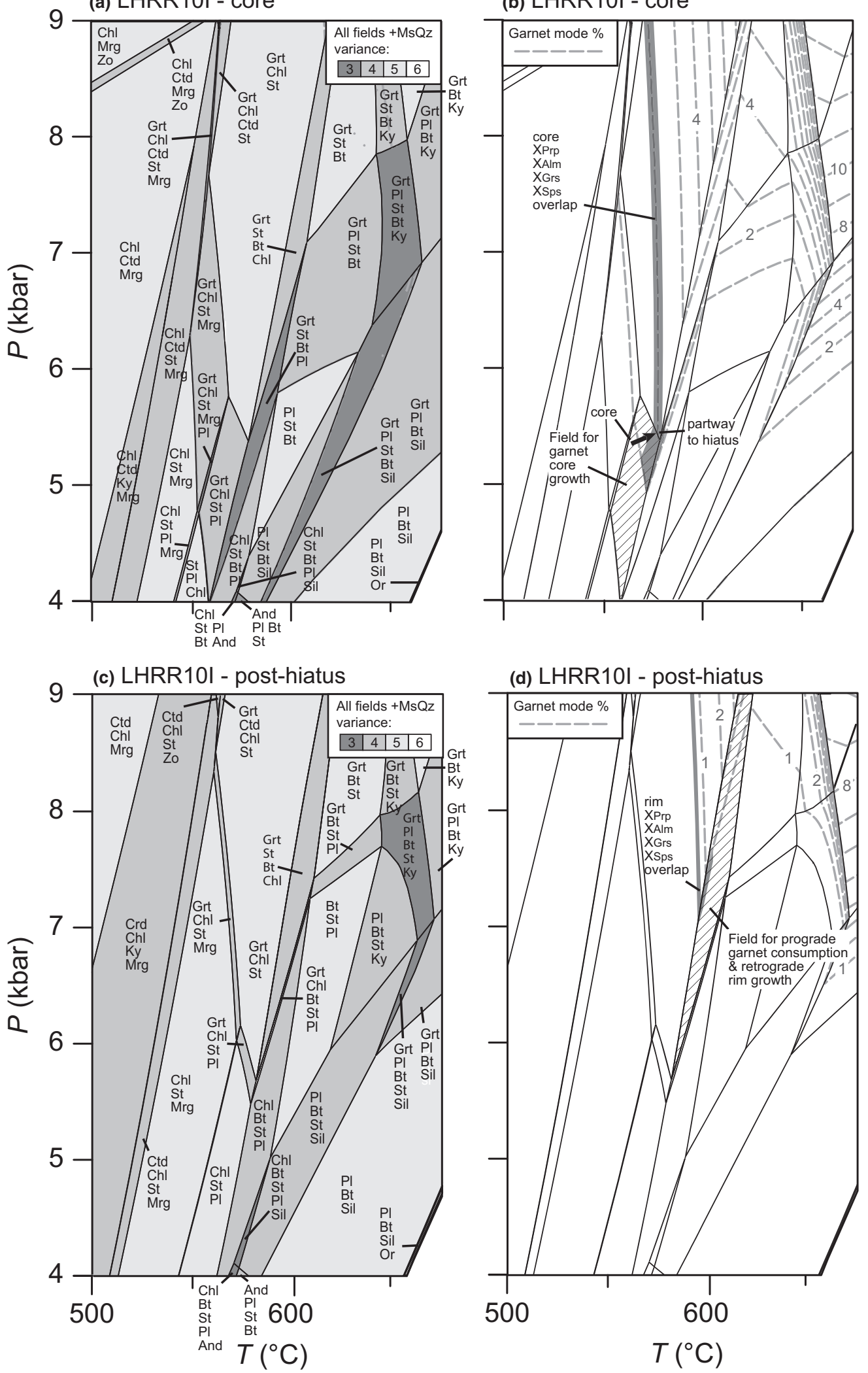

Figure 8. Results of pseudosection modelling for sample LHRR10I. All details as in Fig. 7. The $P-T$ path shown in (b) is displaced $-10{ }^{\circ} \mathrm{C}$ and +150 bar to align the end of the path with the boundary that represents the loss of plagioclase from the assemblage. 
Table 1. Input values used in calculations of isochemical plots, isopleths and $P-T$ paths, and results of $P-T$ path calculations.

\begin{tabular}{|c|c|c|c|c|c|c|c|}
\hline \multicolumn{4}{|c|}{ LHRR10I } & \multicolumn{4}{|c|}{ LHRR10D } \\
\hline & Core $^{\mathrm{a}}$ & Hiatus $^{\mathrm{b}}$ & $\begin{array}{l}\text { Post- } \\
\text { hiatus }^{\mathrm{c}}\end{array}$ & & Core $^{\mathrm{a}}$ & Hiatus $^{\mathrm{b}}$ & $\begin{array}{l}\text { Post- } \\
\text { hiatus }^{\mathrm{c}}\end{array}$ \\
\hline$X_{\operatorname{Prp}}$ & 0.100 & 0.135 & 0.149 & $X_{\operatorname{Prp}}$ & 0.076 & 0.118 & 0.150 \\
\hline$X_{\mathrm{Alm}}$ & 0.746 & 0.795 & 0.786 & $X_{\text {Alm }}$ & 0.706 & 0.746 & 0.778 \\
\hline$X_{\mathrm{Grs}}$ & 0.116 & 0.053 & 0.052 & $X_{\mathrm{Grs}}$ & 0.145 & 0.122 & 0.059 \\
\hline$X_{\mathrm{Sps}}$ & 0.038 & 0.017 & 0.013 & $X_{\mathrm{Sps}}$ & 0.073 & 0.014 & 0.013 \\
\hline$T\left({ }^{\circ} \mathrm{C}\right)^{\mathrm{d}}$ & 575 & & & $T\left({ }^{\circ} \mathrm{C}\right)^{\mathrm{d}}$ & 555 & & \\
\hline$P(\mathrm{kbar})^{\mathrm{e}}$ & 5.25 & & & $P(\mathrm{kbar})^{\mathrm{e}}$ & 5 & & \\
\hline$\Delta M_{\mathrm{Grt}}{ }^{\mathrm{f}}$ & 0.0090 & & & $\Delta M_{\mathrm{Grt}}{ }^{\mathrm{f}}$ & 0.1300 & & \\
\hline$\Delta X_{\mathrm{Grs}}^{\mathrm{f}}$ & -0.0164 & & & $\Delta X_{\mathrm{Grs}}^{\mathrm{f}}$ & -0.0232 & & \\
\hline$\Delta T\left({ }^{\circ} \mathrm{C}\right)^{\mathrm{g}}$ & 12.7 & & & $\Delta T\left({ }^{\circ} \mathrm{C}\right)^{\mathrm{g}}$ & 36.7 & & \\
\hline$\Delta P(\text { bars })^{\mathrm{g}}$ & 97 & & & $\Delta P$ (bars $^{\mathrm{g}}$ & 1134.9 & & \\
\hline n.d. ${ }^{h}$ & 1000 & & & n.d. ${ }^{\mathrm{h}}$ & 220 & & \\
\hline
\end{tabular}

${ }^{\mathrm{a}}$ Garnet core composition.

${ }^{\mathrm{b}}$ Garnet composition at the hiatus.

${ }^{c}$ Average composition of the post-hiatus garnet segment.

${ }^{\mathrm{d}}$ Temperature determined for initiation of garnet growth

${ }^{\mathrm{e}}$ Pressure determined for initiation of garnet growth.

${ }^{\mathrm{f}}$ Monitor value change from the hiatus to core (hiatus minus core). $M_{\mathrm{Grt}}$ is the number of moles of garnet times 1000 .

${ }^{\mathrm{g}}$ Calculated changes in pressure and temperature associated with pre-hiatus (garnet core) growth.

${ }^{\mathrm{h}}$ Nucleation density (nuclei per $100 \mathrm{~cm}^{3}$ ) assumed in garnet growth simulations. Abbreviations follow Whitney \& Evans (2010).

interpreted from the major element profiles (Figs $4 \mathrm{c}$ \& $5 \mathrm{c}$ ) and the REE patterns (Figs $4 \mathrm{~d}-\mathrm{f} \&$ \& $\mathrm{d}-\mathrm{f}$ ). Based on trace and major element variations, we have defined three zones within the garnet grains in this study (Figs 4-6): zone 1 contains the garnet core; zone 2 is the HREE $+Y$ enriched annulus, which either occurs post-hiatus (LHRR10I and THAL4E) or pre-hiatus (THAL6B); and zone 3 consists of the garnet rim post-annulus.

In zone 1, middle and heavy REEs decrease consistent with Rayleigh fractionation from the cores outward (Figs 4d, 5d \& 6d). In samples LHRR10I and THAL4E, growth hiatuses interpreted from major element zoning occur at the boundary between zones 1 and 2. Within zone 2, MREEs and HREEs are enriched, resulting in the annuli observed post-hiatus (Figs 4e, 5e \& 6e). The REE patterns post-annulus (zone 3; Figs 4f, 5f \& 6f) are of markedly different shape than zones 1 and 2, with strong enrichment in MREE and depletion of HREE, which suggests that post-annulus garnet grew coevally with the breakdown of a MREE-enriched phase (e.g. KonradSchmolke et al., 2008).

Garnet grains with annuli rich in HREE $+Y$ have been reported by numerous authors (e.g. Carlson, 2002; Yang \& Rivers, 2002; Corrie \& Kohn, 2008; Gieré et al., 2011). Four mechanisms have been proposed to explain Y annuli in pelitic garnet:

1 Disequilibrium partitioning during changes in kinetic parameters such as garnet growth rate may explain Y annuli. This process commonly produces distinct inclusion-rich and inclusion-free zones (e.g. Yang \& Rivers, 2002), which are not apparent in the garnet in this study.

2 Infiltration of a REE-rich fluid. Textural features indicating fluid flow, such as veins and fluid inclusions may explain $\mathrm{Y}$ zoning, however, these are not observed in this study. Furthermore, this

Table 2. Reduced Lu-Hf data for samples LHRR10I, THAL4E and THAL6B. Points highlighted in grey were not included in age regression calculations.

\begin{tabular}{|c|c|c|c|c|c|c|}
\hline \multirow[b]{2}{*}{ Sample } & \multicolumn{2}{|c|}{ Concentrations ${ }^{\mathrm{a}}$} & \multirow{2}{*}{$\begin{array}{c}\text { Sample } \\
\text { weight }(\mathrm{g})\end{array}$} & \multirow[b]{2}{*}{${ }^{176} \mathrm{Lu} /{ }^{177} \mathrm{Hf}{ }^{b}$} & \multirow[b]{2}{*}{${ }^{176} \mathrm{Hf} /{ }^{177} \mathrm{Hf}^{\mathrm{c}}$} & \multirow[b]{2}{*}{$2 \sigma(\mathrm{abs})^{\mathrm{d}}$} \\
\hline & $\overline{\mathrm{Lu}(\mathrm{ppm})}$ & $\overline{\mathrm{Hf}(\mathrm{ppm})}$ & & & & \\
\hline LHRR10I G1 & 3.44 & 0.417 & 0.24121 & 1.1723 & 0.285711 & 0.000029 \\
\hline LHRR10I G2 & 3.19 & 0.267 & 0.24101 & 1.7192 & 0.287496 & 0.000029 \\
\hline LHRR10I G3 & 3.22 & 0.250 & 0.23622 & 1.8243 & 0.287567 & 0.000029 \\
\hline LHRR10I G4 & 3.34 & 0.448 & 0.24040 & 1.0588 & 0.285985 & 0.000029 \\
\hline LHRR10I G5 & 3.20 & 0.286 & 0.19862 & 1.5879 & 0.286868 & 0.000029 \\
\hline LHRR10I WR & 0.222 & 1.95 & 0.24775 & 0.0161 & 0.282483 & 0.000028 \\
\hline THAL4E G1 & 3.31 & 0.357 & 0.16932 & 1.3171 & 0.285763 & 0.000029 \\
\hline THAL4E G2 & 2.96 & 0.419 & 0.18770 & 1.0015 & 0.284958 & 0.000028 \\
\hline THAL4E G3 & 3.31 & 0.519 & 0.15808 & 0.9046 & 0.284690 & 0.000028 \\
\hline THAL4E G4 & 2.98 & 0.332 & 0.19828 & 1.2749 & 0.286112 & 0.000029 \\
\hline THAL4E G5 & 3.07 & 0.672 & 0.17645 & 0.6489 & 0.284064 & 0.000028 \\
\hline THAL4E GC & 5.13 & 0.085 & 0.24225 & 8.6346 & 0.304710 & 0.000030 \\
\hline THAL4E WR & 0.385 & 8.60 & 0.25569 & 0.0064 & 0.282112 & 0.000028 \\
\hline THAL6B G1 & 10.2 & 0.053 & 0.19942 & 27.79 & 0.349589 & 0.000035 \\
\hline THAL6B G2 & 10.8 & 0.068 & 0.19999 & 22.97 & 0.338332 & 0.000034 \\
\hline THAL6B G3 & 12.4 & 0.087 & 0.20013 & 20.35 & 0.333442 & 0.000033 \\
\hline THAL6B G4 & 11.7 & 0.068 & 0.18864 & 24.59 & 0.338781 & 0.000034 \\
\hline THAL6B G5 & 10.6 & 0.060 & 0.20965 & 25.49 & 0.344912 & 0.000034 \\
\hline THAL6B WR & 0.174 & 0.091 & 0.21024 & 0.2709 & 0.282144 & 0.000028 \\
\hline
\end{tabular}

${ }^{\mathrm{a}} \mathrm{Lu}$ and $\mathrm{Hf}$ concentrations determined by isotope dilution with uncertainties estimated to be better than $0.5 \%$.

${ }^{\mathrm{b}} \mathrm{Uncertainties} \mathrm{for}{ }^{176} \mathrm{Lu} /{ }^{177} \mathrm{Hf}$ for regressions and age calculations are estimated to be $0.5 \%$.

${ }^{c 176} \mathrm{Hf} /{ }^{177} \mathrm{Hf}$ ratios were corrected for instrumental mass bias using ${ }^{179} \mathrm{Hf} /{ }^{177} \mathrm{Hf}=0.7935$ and normalized relative to ${ }^{176} \mathrm{Hf} /{ }^{177} \mathrm{Hf}=0.282160$ for JMC-475 (Vervoort \& Blichert-Toft, 1999$)$. Ages were calculated using the ${ }^{176} \mathrm{Lu}$ decay constant value of Scherer et al. (2001) and Söderlund et al. (2004).

${ }^{\mathrm{d}}$ Reported errors on ${ }^{176} \mathrm{Hf} /{ }^{177} \mathrm{Hf}$ represent within-run uncertainty expressed as $2 \sigma$, standard error. Estimated total uncertainty on individual ${ }^{176} \mathrm{Hf} /{ }^{177} \mathrm{Hf}$ measurements is estimated to be $0.01 \%$ or $\sim 1 \varepsilon \mathrm{Hf}$ unit. These are added to the within-run uncertainties in quadrature for regressions and age calculations. 

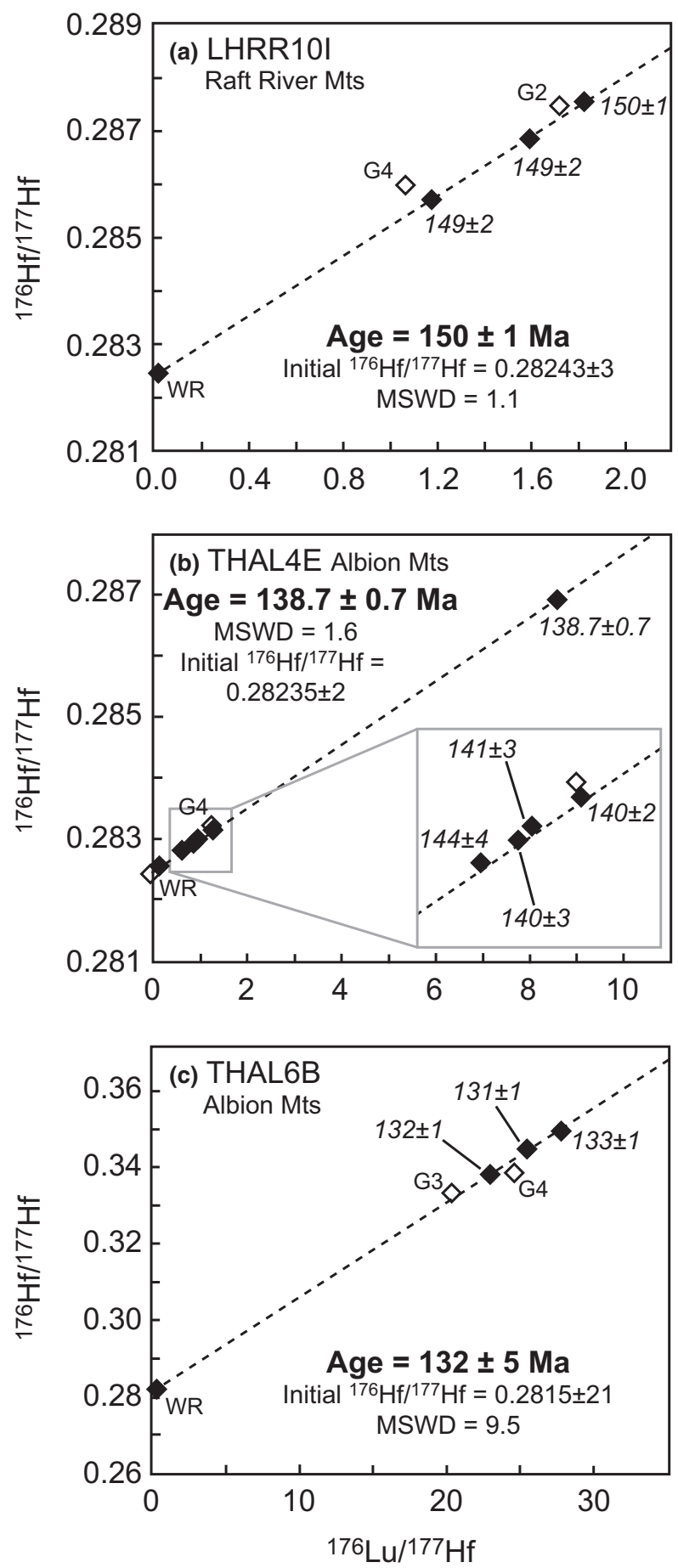

Fig. 9. Lu-Hf garnet isochron plots for samples (a) LHRR10I, (b) THAL4E and (c) THAL6B. Symbols are larger than two sigma error bars. Open squares were not included in the regression and are labelled individually. All whole-rock points are labelled WR; all other points are garnet fractions.

Individual garnet fraction dates (Ma) are labelled in italics. See text for details.

mechanism is commonly invoked to explain oscillatory zoning in trace elements (e.g. Moore et al., 2013), which is also absent.
3 Resorption of garnet during a hiatus and renewed growth may explain $\mathrm{Y}$ zoning. This interpretation is consistent with the results of the $P-T$ modelling for samples LHRR10I and THAL4E. Both rocks have growth paths that cross regions of $P-T$ space in which garnet was consumed and then regrown, producing the observed hiatuses and garnet rims (for instance, garnet rims in samples LHRR10I and $10 \mathrm{D}$ grew in the striped regions of Figs $7 \mathrm{~d} \& 8 \mathrm{~d}$ ). As garnet was consumed, HREE $+\mathrm{Y}$ could have been enriched in the surrounding matrix due to slow matrix diffusion away from the garnet (e.g. Skora et al., 2006). When garnet regrew following resorption, the enriched area would have been overgrown, resulting in the REE patterns in zone 2 that mimic the shape of those in zone 1 but at higher concentrations (Fig. 4). Given the coincidence of HREE + Y annuli post-growth-hiatus interpreted from major element zoning, this explanation is permissive for samples LHRR10I and THAL4E. However, it would not explain the pre-hiatus annulus in sample THAL6B. Additionally, this mechanism commonly results in $\mathrm{Mn}$ resorption into garnet (e.g. Carlson, 2002), which is not observed.

4 Breakdown of a REE-bearing phase such as monazite, apatite, allanite or xenotime may explain $\mathrm{Y}$ annuli. The HREE $+Y$ annuli observed in these rocks are most likely the result of the breakdown of xenotime based on three main lines of evidence: (i) The annuli, particularly in sample LHRR10I, are similar in shape to those reported for accessory phase breakdown (e.g. Pyle \& Spear, 1999; Spear \& Pyle, 2002; Yang \& Rivers, 2002; Gieré et al., 2011). (ii) The REEs within the annuli (zone 2; Figs $4 \mathrm{e}, 5 \mathrm{e} \& 6 \mathrm{e}$ ) show flat HREE patterns which are enriched in MREE and HREE relative to LREE, consistent with the shape of REE patterns reported for xenotime by Spear \& Pyle (2002). (iii) The $\mathrm{Ca}$ and $\mathrm{Y}$ element maps for sample LHRR10I (Fig. 2a) show that apatite inclusions occur throughout the garnet, but xenotime occurs only in the core of the garnet (pre-annulus), which is consistent with the interpretation that the HREE + Y annulus formed by breakdown of xenotime. Only a small number of garnet grains from sample LHRR10I were mapped, so this does not exclude the possibility that xenotime occurs in other garnet rims, but in the garnet grains we have examined xenotime does not occur in the post-annulus rims.

Although it is possible that different mechanisms are responsible for the annuli in each individual rock in this study, we believe the breakdown of a REEbearing phase (mechanism 4 ) is the most likely explanation for the $\mathrm{Y}$ annuli observed in the garnet.

\section{Linking trace elements and Lu-Hf geochronology}

The $\mathrm{Lu}$ distribution in garnet determines what part of the garnet growth history is likely being dated by 
the Lu-Hf method, whether the determined age represents the core, rim or middle. A common interpretation of $\mathrm{Lu}-\mathrm{Hf}$ dates is that they are biased towards the garnet core due to preferential partitioning of $\mathrm{Lu}$ into the core (e.g. Lapen et al., 2003; Skora et al., 2006; Kohn, 2009). However, this interpretation cannot apply to the garnet grains in this study because of the bimodal distribution of $\mathrm{Lu}$, with a large amount of the $\mathrm{Lu}$ being hosted close to the rim within the high HREE+Y annuli (zone 2, Figs 4-6).

To determine the significance of the Lu-Hf garnet ages with respect to the garnet growth history, we estimated the relative amount of Lu present per volume of garnet analysed from core to rim (Fig. 10). Shown for comparison is the volume relationship for a hypothetical garnet that sequestered Lu by Rayleigh fractionation from a uniform reservoir. Of all of the samples, THAL6B shows a $\mathrm{Lu}$ distribution most similar to that predicted by Rayleigh fractionation. The Lu annulus in this sample is closer to the centre of the garnet than in the other two samples, and the magnitude of the $\mathrm{Lu}$ annulus spike is smaller, consistent with its similarity to the ideal Rayleigh garnet. Samples THAL4E and LHRR10I, however, show Lu distributions markedly different than the ideal Rayleigh garnet. The Lu annuli in these samples skew the distribution of $\mathrm{Lu}$ towards the middle/rims of the garnet. This suggests that the Lu-Hf dates determined for samples LHRR10I and THAL4E represent an overall age for garnet growth, more

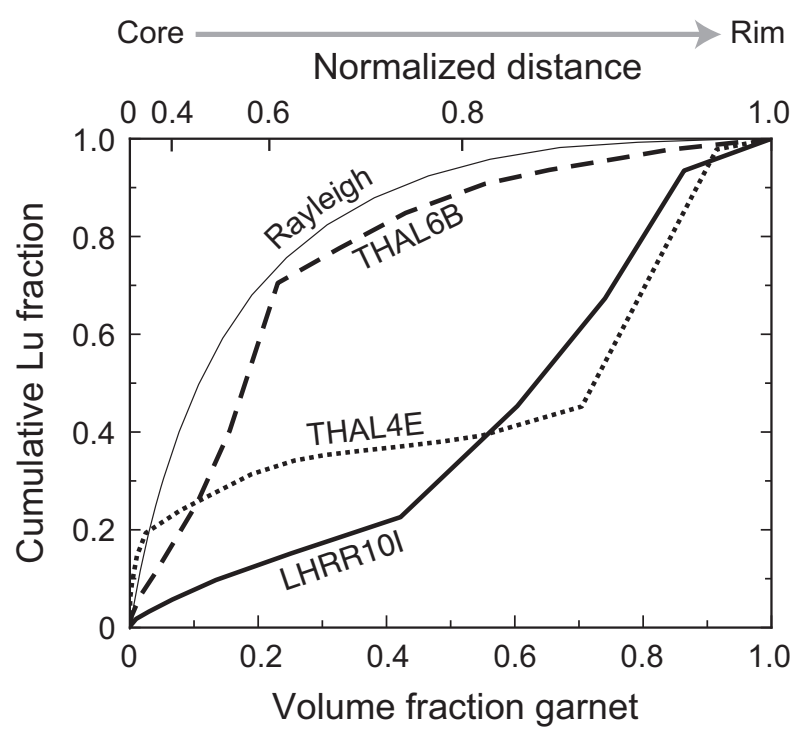

Fig. 10. Plot of volume fraction of garnet $v$. cumulative $\mathrm{Lu}$ fraction in garnet for samples LHRR10I (thick solid line), THAL4E (short dashes) and THAL6B (long dashes) based on $\mathrm{Lu}$ trace element zoning profiles. Shown for comparison is a curve for a hypothetical garnet that grew as a result of Rayleigh fractionation, assuming that garnet growth was linear with area (thin solid line). Upper $\mathrm{X}$-axis shows normalized distance across garnet from core (left) to rim (right). strongly weighted towards the rims, whereas the $\mathrm{Lu}-\mathrm{Hf}$ date for sample THAL6B is representative of mostly core garnet growth. This interpretation assumes Lu is distributed similarly within all the garnet in the rock, which we know may not be the case based on the different zoning profiles in the two garnet grains analysed from sample THAL4E.

A bimodal distribution of $\mathrm{Lu}$ in garnet has potential implications for the interpretation of Lu-Hf garnet dates. Recent studies have successfully dated different zones of garnet growth by microdrilling to physically separate garnet cores, middles and rims (Pollington \& Baxter, 2010; Dragovic et al., 2012), allowing for the determination of the duration and rate of garnet growth. In all samples dated here, each dated garnet fraction is essentially a physical mixture of garnet cores, middles and rims (zones 1, 2, 3 of Figs 4-6). This means that any given point on the isochron is influenced, to varying degrees, by all three zones of garnet. The trace element analysis above suggests that the dates are biased towards zone 2 because of the distribution of $\mathrm{Lu}$ in these garnet grains. Although there is not excessive scatter in the data, particularly for samples LHRR10I and THAL4E, there are some points for each sample that do not lie exactly on the same isochron as the others.

In the absence of analytical reasons for excluding points from a Lu-Hf isochron, we consider a reasonable geological explanation of points that lie above the isochron to be the result of the influence of older zone 1 cores (e.g. Kohn, 2009). Conversely, points that lie below the calculated isochron may have more influence from the garnet rims (zones $2 \& 3$ ). Thus, in natural garnet systems, assigning an isochron date is not necessarily straightforward because the scatter in the data may have geological meaning. When that scatter is smaller than the precision of the method, we cannot see the effects on the date determination. If the opposite is the case, then the scatter may be due, in part, to the duration of garnet growth.

For instance, the Lu-Hf isochron date of $150 \pm 1$ Ma for LHRR10I (Fig. 9a) from the Raft River Mountains includes the three youngest garnet fractions for that sample. Garnet fraction G2, which lies above the isochron, may have more influence from zone 1 of the garnet cores, represented by the peak in $\mathrm{Lu}$ at the centre of the garnet (Fig. 4a). The two-point isochron model date of $152 \pm 1 \mathrm{Ma}$ for this garnet fraction is potentially representative of a minimum date for the onset of garnet growth in this rock, as it may have more influence from older garnet cores. However, this date is not statistically different than the isochron date, which suggests that the duration of garnet growth is short with respect to the date determination.

Based on the garnet Lu-Hf ages and the analysis of what they represent in terms of the garnet growth history, it is possible to relate the ages to the determined $P-T$ paths. For LHRR10I, the $150 \pm 1 \mathrm{Ma}$ 
age likely represents the post-hiatus segment of garnet growth as most of the $\mathrm{Lu}$ is hosted in that segment (Fig. 4). This indicates that the $P-T$ path determined for the core (Fig. 8b), which records an episode of steep pressure increase, is slightly older than $150 \pm 1 \mathrm{Ma}$. For THAL4E, the $138.7 \pm$ $0.7 \mathrm{Ma}$ age probably slightly post-dates the composite N-shaped path determined by Harris et al. (2007) (Fig. 11a), as the path was determined entirely from the core (pre-hiatus) portions of three garnet grains, whereas most of the $\mathrm{Lu}$ is hosted in the post-hiatus segments (Fig. 5). For THAL6B, the $132 \pm 5 \mathrm{Ma}$ age likely represents the age around the end of the steep pressure increase $P-T$ path that was generated from the pre-hiatus segment (Fig. 11a), as the $\mathrm{Lu}$ is hosted mainly in the annulus just before the hiatus (Fig. 6).

\section{Tectonic implications}

In the western Raft River Mountains, a summary $P-T$ path involving a pressure increase of $\sim 2 \mathrm{kbar}$ and a temperature increase of $\sim 50{ }^{\circ} \mathrm{C}$ (Fig. $11 \mathrm{~b}$ ) was interpreted from the isochemical plots and garnet growth simulations from samples LHRR10D and LHRR10I. The relatively short duration of garnet growth suggested by individual garnet fraction dates and the overall tectonic setting suggests that this pressure increase is the result of rapid tectonic burial. The previously described analysis of the distribution of $\mathrm{Lu}$ in garnet from LHRR10I (Fig. 10) suggests that the $\mathrm{Lu}-\mathrm{Hf}$ date from this sample is skewed towards the post-hiatus or outer pre-hiatus segments, indicating that the age likely post-dates the $P-T$ path recorded in the central core. Therefore, the combined $\mathrm{Lu}-\mathrm{Hf}$ geochronology and $P-T$ modelling from sam- ple LHRR10I indicate that major crustal thickening in this portion of the hinterland of the Sevier belt occurred slightly before $150 \mathrm{Ma}$.

The composite $P-T$ path reported by Harris et al. (2007) based on multiple garnet grains from Albion Mountains sample THAL4E (Fig. 11a) shows a nearly isothermal pressure increase followed by a pressure decrease with some heating and then a second nearly isothermal pressure increase. Harris et al. (2007) interpreted the pressure increases to be the result of thrust burial. The previously described analysis of the distribution of $\mathrm{Lu}$ in garnet from THAL4E suggests that the Lu-Hf date of $138.7 \pm 0.7 \mathrm{Ma}$ either post-dates the recorded $P-T$ path or dates near the tail end of it. Thus, a major Early Cretaceous burial episode is recorded by garnet growth in the Albion Mountains.

The Late Jurassic to Early Cretaceous tectonic burial documented here is the oldest Phanerozoic contractional event to have affected the metamorphic rocks in the Raft River-Albion-Grouse Creek metamorphic core complex. These rocks likely lay sufficiently far to the east of the Roberts Mountain and Golconda thrusts to have escaped tectonic burial during the Palaeozoic Antler and Sonoman orogenic events. Furthermore, Late Jurassic to Early Cretaceous contraction is the oldest of several episodes of Mesozoic to Early Cenozoic contraction (e.g. Wells et al., 2012). Therefore, we infer that the tectonic burial required to bring these supracrustal strata to the depths at which garnet growth began was also of Late Jurassic age. Thus, in addition to the $2-3 \mathrm{kbar}$ $(\sim 7-11 \mathrm{~km})$ of burial recorded during garnet growth, a further tectonic burial of $5-9 \mathrm{~km}$ is required to bring the schist of Mahogany Peaks from stratigraphic burial depths of $\sim 10-14 \mathrm{~km}$ to the $\sim 5 \mathrm{kbar}$ (a) Albion Mountains

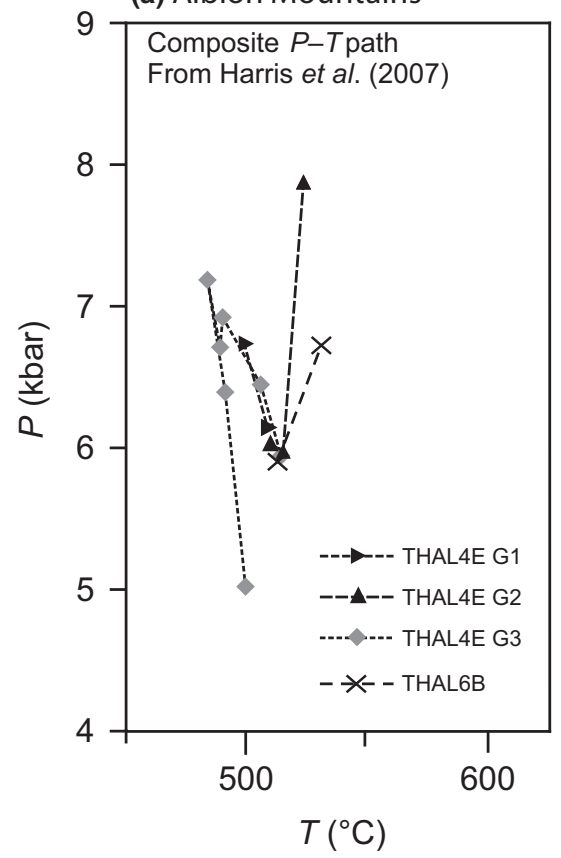

(b) Raft River Mountains

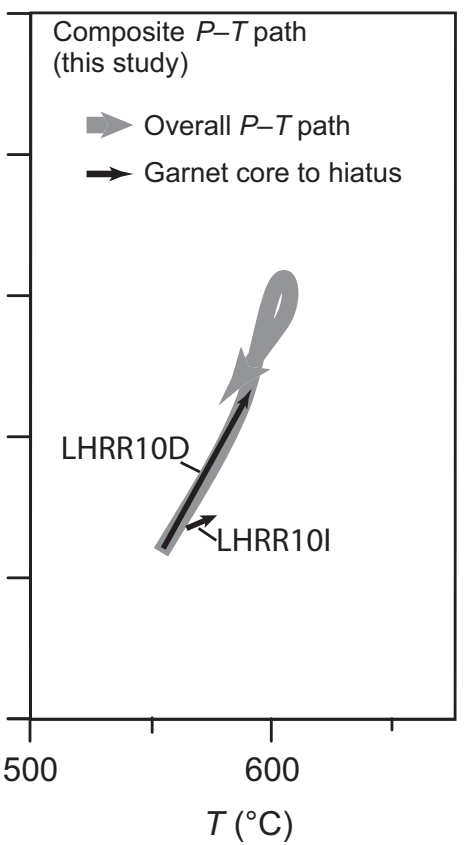

Fig. 11. (a) Composite $P-T$ path for the Albion Mountains modified from Harris et al. (2007) by reinterpreting the path for THAL6B to include only the first segment of the garnet that was simulated. The boundary between the first and second segments was reinterpreted in this study to represent a hiatus similar to THAL4E, LHRR10D and LHRR10I. (b) $P-T$ path for the Raft River Mountains (grey line) based on calculated $P-T$ paths from the garnet cores to the hiatuses, final mineral assemblage fields and post-hiatus garnet rim isopleths. At the high $P-T$ end, the path crosses through the final mineral assemblage field first in the prograde direction, whereupon garnet is consumed, then in the retrograde direction, whereupon garnet is regrown. 
metamorphic conditions at which garnet initiated growth. In summary, $12-20 \mathrm{~km}$ of tectonic burial is required in the Raft River-Albion-Grouse Creek core complex, west of the Wyoming salient of the fold-thrust belt, during the Late Jurassic to Early Cretaceous.

Minor Late Jurassic shortening in the hinterland has previously been recognized, including small offset thrust faults and the upgrading of cleavages in the thermal aureoles of Late Jurassic plutons (e.g. Allmendinger \& Jordan, 1984; Miller et al., 1988; Miller \& Allmendinger, 1991; Hudec, 1992; Smith et al., 1993). However, the unambiguous result from this study of major crustal thickening in the Sevier hinterland during the Late Jurassic to Early Cretaceous suggests that this record of early crustal thickening may be commonly obscured by the Late Cretaceous metamorphism that is pervasive in the mid-crustal rocks of the core complexes (Miller \& Gans, 1989; Camilleri \& Chamberlain, 1997; Lewis et al., 1999; McGrew et al., 2000; Wells et al., 2012; Hallett \& Spear, 2015).

The Late Jurassic to Early Cretaceous (Tithonian to Valanginian) $\mathrm{Lu}-\mathrm{Hf}$ dates reported here for crustal shortening in the Sevier belt hinterland fill in an important temporal gap between documented and significant Early to Middle Jurassic shortening in the western hinterland and mid- to Late Cretaceous shortening in the fold-thrust belt (e.g. Smith et al., 1993; Camilleri et al., 1997; Wyld, 2002; DeCelles, 2004). These new age constraints support a protracted Late Jurassic to early Cenozoic deformation history for the Sevier orogen rather than a two-stage history (e.g. Smith et al., 1993). We concur with previous studies (e.g. Camilleri et al., 1997; DeCelles, 2004) that the Sevier orogenic belt evolved as a retroarc orogenic wedge, with initial shortening propagating to the east through time as the wedge lengthened (e.g. Davis et al., 1983).

\section{CONCLUSIONS}

This study demonstrates that the method of combining $P-T$ paths determined from growth zoning in garnet with $\mathrm{Lu}-\mathrm{Hf}$ garnet geochronology and in situ trace element analyses of garnet is very effective for recognizing, interpreting and dating deformation events in orogenic belts. Detailed in situ analysis of trace elements in garnet, such as HREE+Y, can provide additional insight into the reactions occurring during garnet growth and highlight both equilibrium and disequilibrium processes affecting garnet growth. This study also highlights the importance of coupling $\mathrm{Lu}-\mathrm{Hf}$ geochronology with an understanding of the distribution of $\mathrm{Lu}$ in garnet to interpret $\mathrm{Lu}-\mathrm{Hf}$ garnet dates with respect to the garnet growth history. The $P-T-t$ paths presented here from the Raft River-Albion-Grouse Creek metamorphic core complex record crustal shortening during the Late Juras- sic to Early Cretaceous, providing some of the first direct dates of shortening in the hinterland of the Sevier orogenic belt that pre-dates development of the foreland fold-thrust belt.

\section{ACKNOWLEDGEMENTS}

The authors thank R. King, A. DuFrane, G. Hart and C. Knaack for the laboratory and analytical assistance in the WSU Radiogenic Isotope and Geochronology Laboratory. We also thank A. Strickland and M. Grove for their help with SHRIMP trace element analyses at Stanford University, and J. Wittke for help with microprobe analyses at Northern Arizona University. We thank N. Daczko and an anonymous reviewer for their insightful and helpful comments on this manuscript. This research was supported by NSF Grants EAR-0610048 to TDH, EAR061009 to MLW and EAR-0609856 to JDV.

\section{REFERENCES}

Allmendinger, R.W. \& Jordan, T.E., 1984. Mesozoic structure of the Newfoundland Mountains, Utah: horizontal shortening and subsequent extension in the hinterland of the Sevier belt. Geological Society of America Bulletin, 95, 1280-1292.

Anczkiewicz, R., Szczepański, J., Mazur, S., Storey, C., Crowley, Q. \& Villa, I.M., 2007. Lu-Hf geochronology and trace element distribution in garnet: implications for uplift and exhumation of ultra-high pressure granulites in the Sudetes, SW Poland. Lithos, 95, 363-380.

Caddick, M.J., Konopasek, J. \& Thompson, A.B., 2010. Preservation of garnet growth zoning and the duration of prograde metamorphism. Journal of Petrology, 51, 23272347.

Camilleri, P.A. \& Chamberlain, K.R., 1997. Mesozoic tectonics and metamorphism in the Pequop Mountains and Wood Hills region, northeast Nevada: implications for the architecture and evolution of the Sevier orogen. Geological Society of America Bulletin, 109, 74-94.

Camilleri, P., Yonkee, W.A., Coogan, J, DeCelles, P., McGrew, A. \& Wells, M.L., 1997. Hinterland to foreland transect through the Sevier Orogen, Northeast Nevada to North central Utah: structural style, metamorphism, and kinematic history of a large contractional orogenic wedge. In: Proterozoic to Recent stratigraphy, tectonics, and volcanology, Utah, Nevada, southern Idaho and central Mexico (eds Link, P.K. \& Kowallis, B.J.). Brigham Young University Geology Studies, 42, 297-309.

de Capitani, C. \& Petrakakis, K., 2010. The computation of equilibrium assemblage diagrams with Theriak/Domino software. American Mineralogist, 95, 1006-1016.

Carlson, W.D., 2002. Scales of disequilibrium and rates of equilibration during metamorphism. American Mineralogist, 87, 185-204.

Cheng, H., King, R.L., Nakamura, E., Vervoort, J.D. \& Zhou, Z., 2008. Coupled Lu-Hf and Sm-Nd geochronology constrains garnet growth in ultra-high-pressure eclogites from the Dabie orogen. Journal of Metamorphic Geology, 26, 741758.

Compton, R.R., 1972. Geologic map of Yost Quadrangle, Box Elder County, Utah and Cassia County, Idaho: U.S. Geological Survey Miscellaneous Geologic Investment Series Map I-672, scale 1:31,680.

Corrie, S.L. \& Kohn, M.J., 2008. Trace-element distributions in silicates during prograde metamorphic reactions: implica- 
tions for monazite formation. Journal of Metamorphic Geology, 26, 451-464. doi:10.1111/j.1525-1314.2008.00769.x.

Corrie, S.L., Kohn, M.J. \& Vervoort, J.D., 2010. Young eclogite from the Greater Himalayan Sequence, Arun Valey, eastern Nepal: $P-T-t$ path and tectonic implications. Earth and Planetary Science Letters, 289, 406-416.

Crittenden, M.D., Coney, P.J. \& Davis, G.H., 1980. Cordilleran metamorphic core complexes. Geological Society of America Memoir, 153, 490.

Davis, D., Suppe, J. \& Dahlen, F.A., 1983. Mechanics of foldand-thrust belts and accretionary wedges. Journal of Geophysical Research, 88, 1153-1172.

DeCelles, P.G., 2004. Late Jurassic to Eocene evolution of the Cordilleran thrust belt and foreland basin system, western U.S.A. American Journal of Science, 304, 105-168.

Dragovic, B., Samanta, L.M., Baxter, E.F. \& Selverstone, J., 2012. Using garnet to constrain the duration and rate of water-releasing metamorphic reactions during subduction: an example from Sifnos, Greece. Chemical Geology, 314-317, 922.

Egger, A.E., Dumitru, T.A., Miller, E.L., Savage, C.F.I. \& Wooden, J.L., 2003. Timing and nature of Tertiary plutonism and extension in the Grouse Creek Mountains, Utah. International Geology Review, 45, 497-532.

Endo, S., Wallis, S., Hirata, T. et al., 2009. Age and early metamorphic history of the Sanbagawa belt: Lu-Hf and $P-T$ constraints form the Western Iratsu eclogite. Journal of Metamorphic Geology, 27, 371-384. doi:10.1111/j.15121341.2009.00821.x.

Gieré, R., Rumble, D., Günther, D., Connolly, J. \& Caddick, M.J., 2011. Correlation of growth and breakdown of major and accessory minerals in metapelites from Campolungo, Central Alps. Journal of Petrology, 52, 2293-2334. doi:10.1093/petrology/egr043.

Hallett, B.W. \& Spear, F.S., 2015. Monazite, zircon, and garnet growth in migmatitic pelites as a record of metamorphism and partial melting in the East Humboldt Range, Nevada. American Mineralogist, 100, 951-972.

Harris, C.R., Hoisch, T.D. \& Wells, M.L., 2007. Construction of a composite pressure-temperature path: revealing the synorogenic burial and exhumation history of the Sevier hinterland, USA. Journal of Metamorphic Geology, 25, 915934.

Heller, P.L., Bowdler, S.S., Chambers, H.P. et al., 1986. Time of initial thrusting in the Sevier orogenic belt, Idaho-Wyoming and Utah. Geology, 14, 388-391. doi:10.1130/ 00917613(1986) $14<388:$ TOITIT > 2.0.CO;2.

Hoisch, T.D., Wells, M.L. \& Hanson, L.M., 2002. Pressuretemperature paths from garnet zoning: evidence for multiple episodes of thrust burial in the hinterland of the Sevier orogenic belt. American Mineralogist, 87, 115-131.

Hoisch, T.D., Wells, M.L., Beyene, M.A., Styger, S. \& Vervoort, J.D., 2014. Jurassic Barrovian metamorphism in a western U.S. Cordilleran metamorphic core complex, Funeral Mountains, California. Geology, 42, 399-402. doi: $10.1130 / \mathrm{G} 35352.1$.

Hollister, L.S., 1966. Garnet zoning: an interpretation based on Rayleigh fractionation model. Science, 54, 1647-1650.

Hudec, M.R., 1992. Mesozoic structural and metamorphic history of the central Ruby Mountains metamorphic core complex, Nevada. Geological Society of America Bulletin, 104, $1086-1100$

King, R.L., Bebout, G.E., Kobayashi, K., Nakamura, E. \& van der Klauw, S.N.G.C., 2004. Ultrahigh-pressure metabasaltic garnets as probes into deep subduction zone chemical cycling. Geochemistry Geophysics Geosystems, 5, Q12J14, doi:10.1029/2004GC000746.

Kohn, M.J., 2009. Models of garnet differential geochronology. Geochimica et Cosmochimica Acta, 73, 170-182. doi:10.1016/j.gca.2008.10.004

Konrad-Schmolke, M., Zack, T., O'Brien, P. \& Jacob, D., 2008. Combined thermodynamic and rare earth element modelling of garnet growth during subduction: examples from ultrahigh-pressure eclogite of the Western Gneiss Region, Norway. Earth and Planetary Science Letters, 272, 488-498.

Kylander-Clark, A.R.C., Hacker, B.R. \& Cottle, J.M., 2013. Laser-ablation split-stream ICP petrochronology. Chemical Geology, 345, 99-112.

Lagos, M., Scherer, E.E., Tomaschek, F. et al., 2007. High precision Lu-Hf geochronology of Eocene eclogite-facies rocks from Syros, Cyclades, Greece. Chemical Geology, 243, $16-36$.

Lapen, T.J., Johnson, C.M., Baumgartner, L.P., Mahlen, N.J., Beard, B.L. \& Amato, J.M., 2003. Burial rates during prograde metamorphism of an ultra-high-pressure terrane: an example from Lago di Cignana, western Alps, Italy. Earth and Planetary Science Letters, 215, 57-72.

Lewis, C., Wernicke, B.P., Selverstone, J. \& Bartley, J.M., 1999. Deep burial of the footwall of the northern Snake Range decollement, Nevada. Geological Society of America Bulletin, 111, 39-51.

Ludwig, K.R., 2003. ISOPLOT 3.00: A Geochronological Toolkit for Microsoft Excel. Berkley Geochronology Center, Berkley, CA, Special Publication, 4 (70 p.).

Mazdab, F.K., 2009. Characterization of flux-grown trace-element-doped titanite using the high-mass-resolution ion microprobe (SHRIMP-RG). The Canadian Mineralogist, 47, 813-831.

McGrew, A.J., Peters, M.T. \& Wright, J.E., 2000. Thermobarometric constraints on the tectonothermal evolution of the East Humboldt Range metamorphic core complex, Nevada. Geological Society of America Bulletin, 112, 45-60.

Miller, D.M., 1983. Allochthonous quartzite sequence in the Albion Mountains, Idaho, and proposed Proterozoic Z and Cambrian correlatives in the Pilot Range, Utah and Nevada. Geological Society of America Memoir, 157, 191-213.

Miller, D.M. \& Allmendinger, R.W., 1991. Jurassic normal and strike-slip faults at Crater Island, northwestern Utah. Geological Society of America Bulletin, 103, 1239-1251.

Miller, E.L. \& Gans, P.B., 1989. Cretaceous crustal structure and metamorphism in the hinterland of the Sevier thrust belt, western U.S. Cordillera. Geology, 17, 59-62.

Miller, E.L., Gans, P.B., Wright, J.E. \& Sutter, J.F., 1988. Metamorphic history of the east-central Basin and Range province: tectonic setting and relationship to magmatism. In: Metamorphism and Crustal Evolution of the Western United States (ed. Ernst, W.G.), pp. 649-682. Prentice Hall, Englewood Cliffs, NJ.

Moore, S.J., Carlson, W.D. \& Hesse, M.A., 2013. Origins of yttrium and rare earth element distributions in metamorphic garnet. Journal of Metamorphic Geology, 31, 663-689. doi:10.1111/jmg.12039.

Mottram, C.M., Warren, C.J., Regis, D. et al., 2014. Developing an inverted Barrovian sequence; insights from monazite petrochronology. Earth and Planetary Science Letters, 403, $418-431$.

Otamendi, J.E., de la Rosa, J.D., Patiño Douce, A.E. \& Castro, A., 2002. Rayleigh fractionation of heavy rare earths and yttrium during metamorphic garnet growth. Geology, 30, 159-162.

Pollington, A.D. \& Baxter, E.F., 2010. High resolution Sm-Nd garnet geochronology reveals the uneven pace of tectonometamorphic processes. Earth and Planetary Science Letters, 293, 63-71. doi:10.1016/j.epsl.2010.02.019.

Pyle, J.M. \& Spear, F.S., 1999. Yttrium zoning in garnet: coupling of major and accessory phases during metamorphic reactions. Geological Materials Research, 1, 1-49.

Scherer, E., Cameron, K. \& Blichert-Toft, J., 2000. Lu-Hf garnet geochronology: closure temperature relative to the $\mathrm{Sm}-\mathrm{Nd}$ system and the effects of trace mineral inclusions. Geochimica et Cosmochimica Acta, 64, 3413-3432.

Scherer, E., Munker, C. \& Mezger, K., 2001. Calibration of the Lutetium-Hafnium Clock. Science, 293, 683-686. 
Skora, S., Baumgartner, L.P., Mahlen, N.J., Johnson, C.M., Pilet, S. \& Hellebrand, E., 2006. Diffusion-limited REE uptake by eclogite garnets and its consequences for Lu-Hf and Sm-Nd geochronology. Contributions to Mineralogy and Petrology, 152, 703-720. doi:10.1007/s00410-0060128-x.

Smith, D. L., Miller, E. L., Wyld, S. J. \& Wright, J. E., 1993. Progression and timing of Mesozoic crustal shortening in the northern Great Basin, western U.S.A. In: Mesozoic Paleogeography of the Western United States-II Pacific section (eds Dunn, G. \& McDougall, K.), pp. 389-406. Society of Economic Paleontologists and Mineralogists, Book 71. 389406.

Söderlund, W. Patchett, P.J., Vervoort, J.D. \& Isachsen, C.E., 2004. The ${ }^{176} \mathrm{Lu}$ decay constant determined by Lu-Hf and $\mathrm{U}-\mathrm{Pb}$ isotope systematics of Precambrian mafic intrusions. Earth and Planetary Science Letters, 219, 311-324.

Spear, F.S., 1988. Metamorphic fractional crystallization and internal metasomatism by diffusional homogenization of zoned garnets. Contributions to Mineralogy and Petrology, 99, 507-517.

Spear, F.S., 1995. Metamorphic Phase Equilibria and PressureTemperature-Time Paths. Mineralogical Society of America, Washington, DC, 799 pp.

Spear, F.S. \& Pyle, J.M., 2002. Apatite, monazite, and xenotime in metamorphic rocks. Reviews in Mineralogy and Geochemistry, 48, 298-335.

Spear, F.S., Peacock, E.M., Kohn, M.J., Florence, F.P. \& Menard, T., 1991. Computer programs for petrologic PT-t path calculations. American Mineralogist, 76, 2009-2012.

Vervoort, J.D. \& Blichert-Toft, J., 1999. Evolution of the depleted mantle: Hf isotope evidence from juvenile rocks through time. Geochimica et Cosmochimica Acta, 63, 533556.

Vervoort, J.D., Patchett, P.J., Söderlund, U. \& Baker, M., 2004. Isotopic compositions of $\mathrm{Yb}$ and the determination of $\mathrm{Lu}$ concentrations and $\mathrm{Lu} / \mathrm{Hf}$ ratios by isotopic dilution using MC-ICPMS. Geochemistry Geophysics Geosystems, 5, doi:10.1029/2004GC000721.

Wells, M.L., 1997. Alternating contraction and extension in the hinterlands of orogenic belts: an examples from the Raft River Mountains, Utah. Geological Society of America Bulletin, 109, 107-126.

Wells, M.L., Hoisch, T.D., Peters, M.T., Miller, D.M., Wolff, E.D. \& Hanson, L.M., 1998. The Mahogany Peaks fault, a Late Cretaceous-Paleocene normal fault in the hinterland of the Sevier Orogen. Journal of Geology, 106, 623-634.

Wells, M.L., Snee, L.W. \& Blythe, A.E., 2000. Dating of major normal fault systems using thermochronology: an example from the Raft River detachment, Basin and Range, western
United States. Journal of Geophysical Research, 105, 16303 16327.

Wells, M.L., Hoisch, T.D., Cruz-Uribe, A.M. \& Vervoort, J.D., 2012. Geodynamics of synconvergent extension and tectonic mode switching: constraints from the Sevier-Laramide orogen. Tectonics, 31, TC1002, doi:10.1029/2011TC002913.

Whitney, D.L. \& Evans, B.W., 2010. Abbreviations for names of rock-forming minerals. American Mineralogist, 95, 185187.

Wyld, S.J., 2002. Structural evolution of a Mesozoic backarc fold-and-thrust belt in the U.S. Cordillera: new evidence from northern Nevada. Geological Society of America Bulletin, 114, 1452-1468.

Yang, P. \& Rivers, T., 2002. The origin of Mn and Y annuli in garnet and the thermal dependence of $\mathrm{P}$ in garnet and $\mathrm{Y}$ in apatite in calc-pelite and pelite, Gagnon terrane, western Labrador. American Mineralogist, 88, 1398-1398.

Yonkee, W.A., Dehler, C.D., Link, P.K., et al., 2014. Tectonostratigraphic framework of Neoproterozoic to Cambrian strata, west-central U.S.: protracted rifting, glaciation, and evolution of the North American Cordilleran margin. EarthScience Review, 156, 59-95.

\section{SUPPORTING INFORMATION}

Additional Supporting Information may be found in the online version of this article at the publisher's web site:

Appendix S1. Major element garnet traverse data expressed as mole fractions $X_{\mathrm{Alm}}, X_{\mathrm{Sps}}, X_{\mathrm{Grs}}$ and $X_{\mathrm{Prp}}$ for samples LHRR10I and LHRR10D.

Appendix S2. Representative acquisition parameters for trace element analysis in garnet by SHRIMPRG.

Appendix S3. Detailed description of methods used for thermodynamic modelling of garnet growth.

Figure S1. Plot of $\mathrm{Lu}$ concentration $v$. distance across garnet 2 from sample THAL4E analysed by SHRIMP-RG.

Table S1. Mineral composition data and calculated bulk compositions for samples LHRR10I and LHRR10D.

Received 29 January 2014; revision accepted 3 July 2015. 
Linking thermodynamic modelling, Lu-Hf geochronology, and trace elements in garnet: New $P$-T $-t$ paths from the Sevier hinterland

\author{
A.M. Cruz-Uribe, T. D. Hoisch, M. L. Wells, J. D. Vervoort, F. K. Mazdab
}

Appendix S2: Representative acquisition parameters for trace element analysis in garnet by SHRIMP-RG.

Appendix S3: Detailed description of methods used for thermodynamic modelling of garnet growth.

Figure S1: Plot of Lu concentration versus distance across garnet 2 from sample THAL4E analyzed by SHRIMP-RG.

Table S1: Mineral composition data and calculated bulk compositions for samples LHRR10I and LHRR10D. 
APPENDIX S2. Representative acquisition table for trace element analysis in garnet by SHRIMP-RG

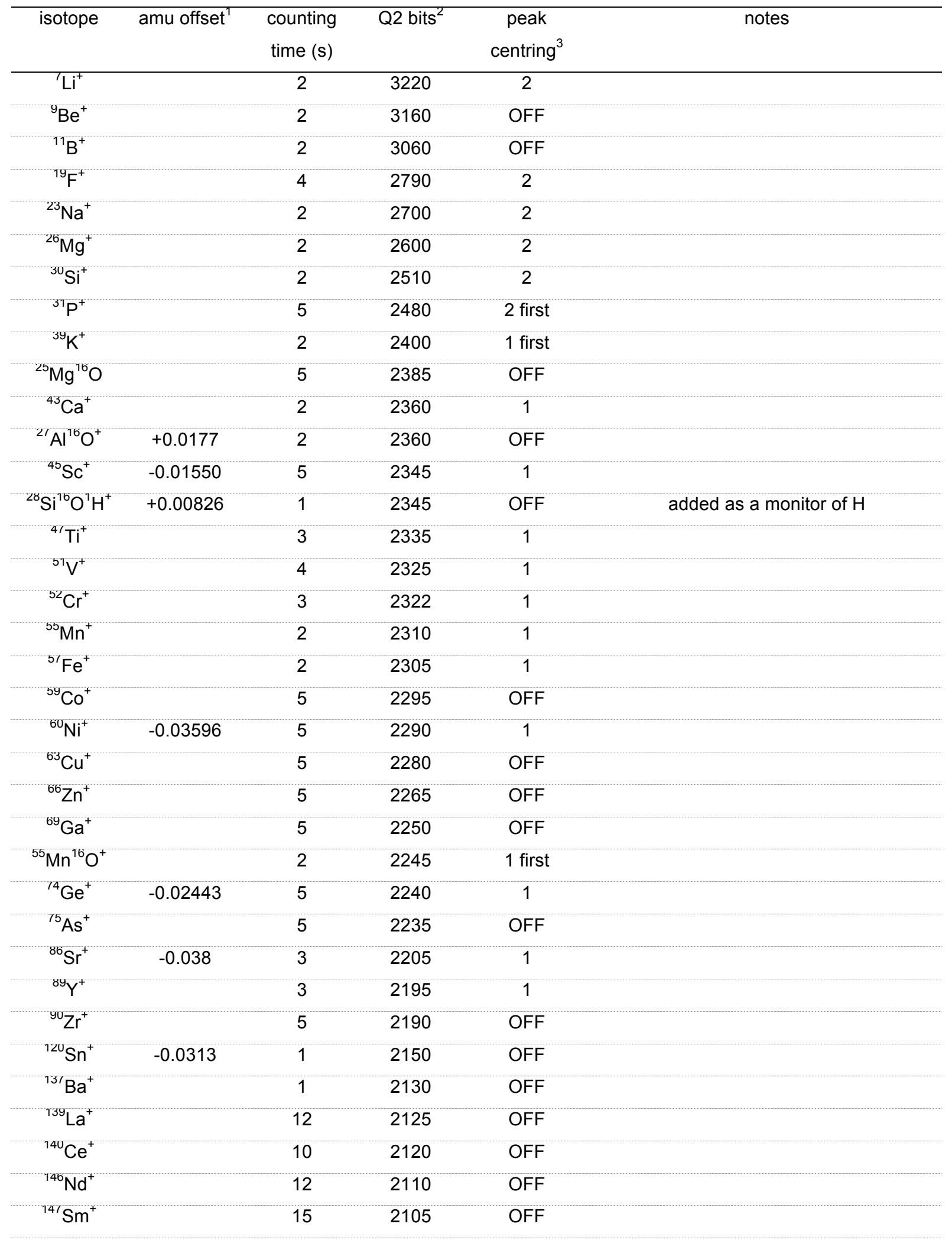




\begin{tabular}{|c|c|c|c|c|}
\hline${ }^{153} \mathrm{Eu}^{+}$ & 12 & 2100 & 3 & \\
\hline${ }^{15 /} \mathrm{Gd}^{16} \mathrm{O}^{+}$ & 12 & 2095 & OFF & \\
\hline${ }^{15 y} \mathrm{~Tb}^{16} \mathrm{O}^{+}$ & 12 & 2092 & OFF & \\
\hline${ }^{163} \mathrm{Dy}^{16} \mathrm{O}^{+}$ & 12 & 2090 & 1 & \\
\hline${ }^{165} \mathrm{Ho}^{16} \mathrm{O}^{+}$ & 15 & 2085 & OFF & \\
\hline${ }^{166} \mathrm{Er}^{16} \mathrm{O}^{+}$ & 15 & 2080 & 3 & \\
\hline${ }^{169} \mathrm{Tm}^{16} \mathrm{O}^{+}$ & 18 & 2078 & OFF & \\
\hline${ }^{1 / 2} \mathrm{Yb}^{16} \mathrm{O}^{+}$ & 18 & 2075 & 3 & \\
\hline${ }^{1 / 3} \mathrm{Lu}^{16} \mathrm{O}^{+}$ & 20 & 2073 & 3 & \\
\hline${ }^{180} \mathrm{Hf}^{16} \mathrm{O}^{+}$ & 20 & 2070 & OFF & \\
\hline${ }^{208} \mathrm{~Pb}^{+}$ & 1 & 2060 & OFF & \\
\hline${ }^{232} \mathrm{Th}^{10} \mathrm{O}^{+}$ & 4 & 2030 & OFF & \\
\hline${ }^{238} \mathrm{U}^{10} \mathrm{O}^{+}$ & 4 & 2025 & OFF & \\
\hline 96 & 1 & 2160 & OFF & added to assist stepdown to $\mathrm{Li}$ \\
\hline 30 & 1 & 2500 & OFF & added to assist stepdown to $\mathrm{Li}$ \\
\hline 18 & 1 & 2800 & OFF & added to assist stepdown to $\mathrm{Li}$ \\
\hline 11 & 1 & 3000 & OFF & added to assist stepdown to $\mathrm{Li}$ \\
\hline 8 & 1 & 3100 & OFF & added to assist stepdown to $\mathrm{Li}$ \\
\hline
\end{tabular}

${ }^{1}$ amu offset from guide peak.

${ }^{2} \mathrm{Q} 2$ bits drift up or down with time (typically in long period [several week] cycles), but the relative differences between masses remain generally the same.

${ }^{3}$ OFF means auto-centring is not used and the peak position is adjusted for magnet drift according to the position of the last previously auto-centred peak; numerical value is time (in seconds) taken for auto-centring; "first" means auto-centring is only performed on the first cycle; otherwise, peaks are auto-centred each cycle. Choice of auto-centring, first or always, and autocentring times have varied over the evolution of the acquisition set-up and may differ slightly between runs. In most cases, peak centring was always turned OFF when the element was known to be absent, to avoid losing a mass position to a nearby interference. 


\section{Appendix S3: Detailed description of methods used for thermodynamic modelling of garnet growth}

The thermodynamic modelling of garnet growth was undertaken through a series of steps: (1) determine the bulk composition of the rock, (2) with the bulk composition and garnet core composition used as inputs for DOMINO, determine the $P-T$ conditions associated with garnet nucleation, (3) with the bulk composition and the $P-T$ conditions of garnet nucleation used as inputs, determine the initial conditions for garnet growth using THERIAK, (4) determine the $P-T$ path for garnet growth using the Gibbs' method based on Duhem's theorem. Further explanation of the steps is provided below.

Bulk compositions were determined by summing mineral compositions in their respective weight proportions. Weight proportions were determined from modes (volume proportions) based on point counting after excluding phases that were not considered to be part of the reactive assemblage (apatite, tourmaline, ilmenite and zircon), and by converting modes to weight proportions using molecular weights and molar volumes for each mineral. Molecular weights and molar volumes for solid solution minerals were determined by summing the values for the endmembers after multiplying by their respective mole fractions. Titanium was excluded from the bulk composition because the thermodynamic database used for the calculations lacks Ti-bearing components for the phases of interest (database $t c d b 55 c 2$ included with THERIAK/DOMINO, based on data from Holland \& Powell, 1998). This resulted in a model system consisting of Na-K-Ca-MgFe-Mn-Al-Si-O-H. Excess $\mathrm{H}_{2} \mathrm{O}$ was added, and all Fe was assumed to be $\mathrm{Fe}^{2+}$. The same system was assumed for the Gibbs' method simulations of garnet growth.

To determine the $P-T$ conditions associated with garnet nucleation, isochemical plots were calculated using the program DOMINO. The isochemical plots were calculated to show mineral assemblage fields and compositional isopleths for the garnet cores (values of $\mathrm{X}_{\mathrm{Prp}}, \mathrm{X}_{\mathrm{Alm}}, \mathrm{X}_{\mathrm{Sps}}$ and $\mathrm{X}_{\mathrm{Grs}}$, all \pm 0.02 ) from $4-8 \mathrm{kbar}$ and $500-675^{\circ} \mathrm{C}$. The overlap of the garnet core isopleth fields indicates both the $P-T$ conditions of garnet nucleation, and the mineral assemblage in which garnet growth began (Figs $7 b$ \& 8b).

The mineral modes and compositions associated with garnet nucleation were calculated with THERIAK using as inputs the pressure and temperature determined from the intersection of the garnet core isopleths and the determined bulk composition. The determined pressure, temperature, modes and mineral compositions comprise the initial conditions needed for Gibbs' method calculations. Garnet growth was simulated using the Gibbs' method based on Duhem's theorem as implemented in the program GIBBS (version dated Feb. 16, 2010; Spear et al., 1991) using the integrated database $S P a C(2007-A u g)$, which uses thermodynamic data from Holland \& Powell (1998). $P$ - $T$ paths were retrieved from the garnet growth simulations as described in detail in the text.

Because garnet is effectively fractionated from the rock during growth, the effective bulk composition changes, causing shifts in the locations of mineral assemblage boundaries and mineral composition isopleths. For this reason, isochemical plots were generated for both the initiation of garnet growth and for post-hiatus garnet growth. To generate the isochemical plot representing the initiation of garnet growth, the full garnet mode was included in the calculation of the bulk composition (Figs 7a,b \& 8a,b; Table S1). To generate the isochemical plot representing the posthiatus segment of garnet growth, only $10 \%$ of the garnet mode was retained in the bulk composition while $90 \%$ was assumed to have fractionated, corresponding to an estimate of the relative volumes of the post-hiatus and pre-hiatus segments in both garnets (Figs 7c,d \& 8c,d; Table S1).

Both garnet grains simulated in this study (samples LHRR10D and LHRR10I) display symmetric major element profiles, with Mn highest in the centre and tapering toward the rim, consistent with Rayleigh fractionation and with the preservation of growth-related chemical zonation (Fig. 3). This is also consistent with the conditions determined for the garnet growth (Figs $7 \& 8$ ), 
which indicate that they remained below thresholds for significant cation diffusion $\left(<600^{\circ} \mathrm{C}\right)$. Both grains also display a growth hiatus that is identified by a discontinuity along the profile, representing an event of partial garnet consumption followed by regrowth.

The DOMINO program determined the following minerals to be stable within the $P-T$ range considered for both bulk compositions: quartz, muscovite, paragonite, biotite, kyanite, sillimanite, andalusite, staurolite, garnet, chlorite, chloritoid, corderite, margarite, zoisite, plagioclase and Kfeldspar. Based on the overlap of garnet core isopleth fields with respect to the mineral assemblage fields, both garnet cores were determined to have grown within the assemblage quartz + muscovite + chlorite + staurolite + garnet + plagioclase (Figs 7a,b \& 8a,b). In order to facilitate the use of mineral compositions determined by THERIAK as initial conditions in GIBBS, mineral solid solution models most similar to those used in dataset $t c d b 55 c 2$ were selected from dataset $S P a C(2007-A u g)$, specifically, mineral 117 for muscovite, 124 for chlorite, 30 for garnet, 40 for staurolite, 93 for plagioclase, 1 for quartz and 2 for water. The multi-site representation of chlorite is identical between the two programs, except for the site nomeclature and the fact that THERIAK reports site occupancies as atom fractions whereas GIBBS requires the input of site-specific formula values based on a formula of 18 oxygen (14 anhydrous). For muscovite, THERIAK reports site occupancies as atom fractions, whereas mineral 117 in dataset $S P a C(2007-A u g)$ requires site-specific formula values based on a formula of 12 oxygen (11 anhydrous). For plagioclase, THERIAK calculates a ternary plagioclase (Na-Ca-K) whereas GIBBS uses a binary model (Na-Ca). Consequently, to use plagioclase compositions calculated by THERIAK as input for GIBBS, the trace amount of Kfeldspar component that was calculated had to be excluded and the sum of albite and anorthite fractions were renormalized to 1. Staurolite and garnet are treated identically between the two programs - both use single-site activity models with compositions represented by atom fractions.

Activity-composition models used in datasets tcdb55c2 and $\mathrm{SPaC}(2007-\mathrm{Aug})$ are noted within the respective datasets. In dataset $t c d b 55 c 2$, non-ideal activity models are used for all of the minerals that co-existed during growth of the garnet core: chlorite (mixing on four sites; Fe-Mg-Mn$\mathrm{Al}$ or subset depending on the specific site), staurolite (Fe-Mg-Mn single-site mixing), garnet (Fe$\mathrm{Mg}-\mathrm{Mn}-\mathrm{Ca}$, single-site mixing), muscovite (mixing on three sites; only K-Na occupies the A-site) and plagioclase (Na-Ca-K single-site mixing). In dataset $S P a C(2007-A u g)$, the solid solutions and mixing models for these minerals are identical except as previously noted for plagioclase, however, only muscovite is non-ideal; all others are ideal models. Previous studies (e.g. Kohn, 1993; Spear \& Selverstone, 1983) have noted that in differential thermobarometry (i.e., Gibbs' method) calculations, non-ideal models yield results that are essentially indistinguishable from results generated with ideal models. Our own tests confirm this.

\section{REFERENCES}

Holland, T.J.B. \& Powell, R., 1998. An internally-consistent thermodynamic dataset for phases of petrological interest. Journal of Metamorphic Geology, 16, 309-344.

Kohn, M.J., 1993. Uncertainties in differential thermodynamic (Gibbs' method) P-T- paths. Contributions to Mineralogy and Petrology, 113, 24-39.

Spear, F.S. \& Selverstone, J., 1983. Quantitative P-T paths from zoned minerals: theory and tectonic applications. Contributions to Mineralogy and Petrology, 83, 348-357. 
Figure S1: Plot of Lu concentration versus distance across garnet 2 from sample THAL4E analyzed by SHRIMP-RG.

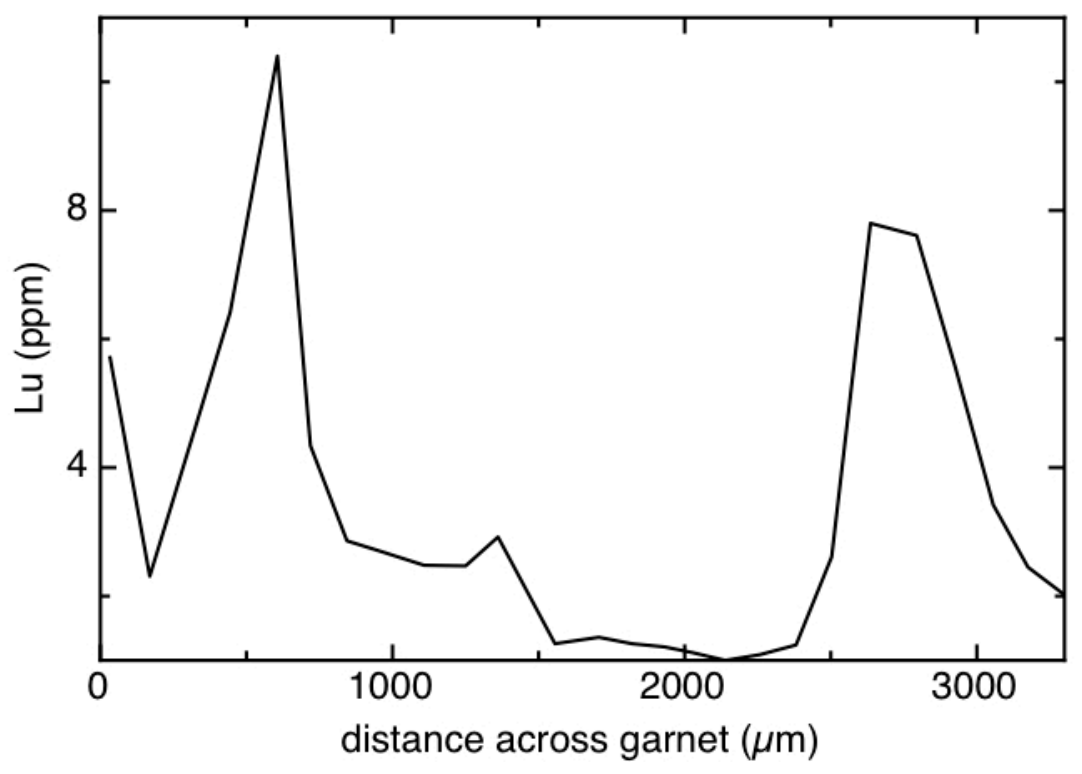


Table S1. Mineral compostion data and calculated bulk compositions for samples LHRR10I and LHRR10D.

\begin{tabular}{|c|c|c|c|c|c|c|c|c|c|c|c|}
\hline \multirow{2}{*}{$\begin{array}{l}\text { sample: } \\
\text { LHRR10i }\end{array}$} & \multirow{2}{*}{\begin{tabular}{r|} 
Mode \\
vol. $\%$
\end{tabular}} & \multicolumn{10}{|c|}{ Chemical composition in weight percents of the oxides } \\
\hline & & $\mathrm{SiO}_{2}$ & $\mathrm{TiO}_{2}$ & $\mathrm{Al}_{2} \mathrm{O}_{3}$ & $\mathrm{FeO}$ & MnO & MgO & $\mathrm{CaO}$ & $\mathrm{Na}_{2} \mathrm{O}$ & $\mathrm{K}_{2} \mathrm{O}$ & Total \\
\hline staurolite & 17.40 & 28.13 & 0.60 & 54.93 & 12.22 & 0.04 & 1.66 & 0.00 & 0.00 & 0.00 & 97.58 \\
\hline muscovite & 43.20 & 45.52 & 0.51 & 34.28 & 4.15 & 0.00 & 2.09 & 0.02 & 1.33 & 7.62 & 95.53 \\
\hline biotite & 14.10 & 36.83 & 1.51 & 18.93 & 16.28 & 0.01 & 12.73 & 0.03 & 0.19 & 8.09 & 94.60 \\
\hline quartz $^{5}$ & 20.70 & 100.00 & 0.00 & 0.00 & 0.00 & 0.00 & 0.00 & 0.00 & 0.00 & 0.00 & 100.00 \\
\hline garnet core & note 3 & 37.53 & 0.00 & 20.49 & 32.45 & 1.63 & 2.44 & 3.95 & 0.00 & 0.00 & 98.48 \\
\hline garnet rim & note 3 & 37.30 & 0.00 & 20.62 & 34.60 & 0.75 & 3.22 & 2.28 & 0.00 & 0.00 & 98.77 \\
\hline chlorite & 1.60 & 24.37 & 0.09 & 22.94 & 24.84 & 0.04 & 14.79 & 0.00 & 0.02 & 0.05 & 87.13 \\
\hline bulk comp. ${ }^{2}$ & $\mathrm{n} / \mathrm{a}$ & 50.66 & 0.55 & 30.03 & 8.47 & 0.05 & 3.36 & 0.13 & 0.58 & 4.30 & 93.26 \\
\hline bulk comp. ${ }^{6}$ & $\mathrm{n} / \mathrm{a}$ & 51.18 & 0.58 & 30.41 & 7.46 & 0.02 & 3.38 & 0.02 & 0.60 & 4.47 & 93.04 \\
\hline \multirow{2}{*}{$\begin{array}{l}\text { sample: } \\
\text { LHRR10d }\end{array}$} & Mode & \multicolumn{10}{|c|}{ Chemical composition in weight percents of the oxides } \\
\hline & vol. \% & $\mathrm{SiO}_{2}$ & $\mathrm{TiO}_{2}$ & $\mathrm{Al}_{2} \mathrm{O}_{3}$ & $\mathrm{FeO}$ & MnO & MgO & $\mathrm{CaO}$ & $\mathrm{Na}_{2} \mathrm{O}$ & $\mathrm{K}_{2} \mathrm{O}$ & Total \\
\hline staurolite & 5.72 & 27.63 & 0.55 & 54.15 & 13.05 & 0.01 & 1.68 & 0.00 & 0.00 & 0.00 & 97.06 \\
\hline muscovite & 56.07 & 46.10 & 0.34 & 36.48 & 0.71 & 0.00 & 0.56 & 0.01 & 2.03 & 8.16 & 94.39 \\
\hline biotite & 13.57 & 36.26 & 1.59 & 18.55 & 15.15 & 0.02 & 12.95 & 0.01 & 0.23 & 8.86 & 93.61 \\
\hline quartz $^{5}$ & 17.14 & 100.00 & 0.00 & 0.00 & 0.00 & 0.00 & 0.00 & 0.00 & 0.00 & 0.00 & 100.00 \\
\hline garnet core & note 7 & 36.92 & 0.00 & 20.47 & 31.16 & 3.03 & 1.90 & 5.10 & 0.00 & 0.00 & 98.58 \\
\hline garnet rim & note 7 & 36.85 & 0.00 & 20.45 & 33.71 & 0.71 & 2.59 & 4.29 & 0.00 & 0.00 & 98.60 \\
\hline chlorite & 1.43 & 24.37 & 0.09 & 22.94 & 24.84 & 0.04 & 14.79 & 0.00 & 0.02 & 0.05 & 87.13 \\
\hline bulk comp. ${ }^{8}$ & $\mathrm{n} / \mathrm{a}$ & 50.36 & 0.44 & 27.79 & 6.23 & 0.11 & 2.39 & 0.39 & 1.12 & 5.58 & 87.72 \\
\hline bulk comp. ${ }^{9}$ & $\mathrm{n} / \mathrm{a}$ & 51.49 & 0.48 & 28.41 & 3.98 & 0.01 & 2.39 & 0.05 & 1.22 & 6.05 & 86.81 \\
\hline
\end{tabular}

1. $\mathrm{H}$ not analyzed. Stoichiometric values of $\mathrm{H}$ were assumed for muscovite, biotite and chlorite. For staurolite, the method of Holdaway et al .

(1991) was used to estimate $\mathrm{H}$. For bulk compositions, excess $\mathrm{H}_{2} \mathrm{O}$ was assumed by entering an $\mathrm{H}$ value of 30 .

2. Bulk composition for the initial phase of garnet growth. Assumed a mode of $0.75 \%$ for the garnet core composition and $2.25 \%$ for the garnet rim composition.

3. The total garnet mode is 3.00. The weightings used in the bulk composition calculations are given in notes 2 and 6.

4. For minerals, values are the number of anhydrous oxygens used normalize mineral formulas, with the exception of staurolite, which is normalized to $\mathrm{Al}+\mathrm{Si}=25.53$, following Holdaway et al . (1991). For bulk compositions, values are the number of cations (10) used to normalize.

5. Pure $\mathrm{SiO}_{2}$ was assumed for quartz.

6. Bulk composition for the post-hiatus phase of garnet growth. Assumed a mode of $0.00 \%$ for the garnet core composition and $0.30 \%$ for the garnet rim composition.

7. The total garnet mode is $6.07 \%$. The weightings used in the bulk composition calculations are given in notes 8 and 9 


\begin{tabular}{|c|c|c|c|c|c|c|c|c|c|c|}
\hline \multicolumn{11}{|c|}{ Normalized compositions } \\
\hline Basis $^{4}$ & Si & $\mathrm{Ti}$ & Al & $\mathrm{Fe}^{2+}$ & $M n$ & $\mathrm{Mg}$ & $\mathrm{Ca}$ & $\mathrm{Na}$ & $\mathrm{K}$ & $\mathrm{H}^{1}$ \\
\hline 25.53 & 7.73 & 0.13 & 17.80 & 2.81 & 0.01 & 0.68 & 0.00 & 0.00 & 0.00 & 3.06 \\
\hline 11.00 & 3.03 & 0.03 & 2.69 & 0.23 & 0.00 & 0.21 & 0.00 & 0.17 & 0.65 & 2.00 \\
\hline 11.00 & 2.75 & 0.09 & 1.67 & 1.02 & 0.00 & 1.42 & 0.00 & 0.03 & 0.77 & 2.00 \\
\hline 2.00 & 1.00 & 0.00 & 0.00 & 0.00 & 0.00 & 0.00 & 0.00 & 0.00 & 0.00 & 0.00 \\
\hline 12.00 & 3.05 & 0.00 & 1.96 & 2.21 & 0.11 & 0.30 & 0.34 & 0.00 & 0.00 & 0.00 \\
\hline 12.00 & 3.03 & 0.00 & 1.97 & 2.35 & 0.05 & 0.39 & 0.20 & 0.00 & 0.00 & 0.00 \\
\hline 14.00 & 2.58 & 0.01 & 2.86 & 2.20 & 0.00 & 2.33 & 0.00 & 0.00 & 0.01 & 4.00 \\
\hline 10.00 & 4.81 & 0.04 & 3.36 & 0.67 & 0.00 & 0.48 & 0.01 & 0.11 & 0.52 & 30.00 \\
\hline 10.00 & 4.85 & 0.04 & 3.39 & 0.59 & 0.00 & 0.48 & 0.00 & 0.11 & 0.54 & 30.00 \\
\hline \multicolumn{11}{|c|}{ Normalized compositions } \\
\hline Basis $^{4}$ & $\mathrm{Si}$ & $\mathrm{Ti}$ & Al & $\mathrm{Fe}^{2+}$ & $M n$ & $\mathrm{Mg}$ & $\mathrm{Ca}$ & $\mathrm{Na}$ & $\mathrm{K}$ & $\mathrm{H}^{1}$ \\
\hline 25.53 & 7.71 & 0.12 & 17.82 & 3.05 & 0.00 & 0.70 & 0.00 & 0.00 & 0.00 & 3.06 \\
\hline 11.00 & 3.06 & 0.02 & 2.85 & 0.04 & 0.00 & 0.06 & 0.00 & 0.26 & 0.69 & 2.00 \\
\hline 11.00 & 2.74 & 0.09 & 1.65 & 0.96 & 0.00 & 1.46 & 0.00 & 0.03 & 0.85 & 2.00 \\
\hline 2.00 & 1.00 & 0.00 & 0.00 & 0.00 & 0.00 & 0.00 & 0.00 & 0.00 & 0.00 & 0.00 \\
\hline 12.00 & 3.02 & 0.00 & 1.97 & 2.13 & 0.21 & 0.23 & 0.45 & 0.00 & 0.00 & 0.00 \\
\hline 12.00 & 3.01 & 0.00 & 1.97 & 2.30 & 0.05 & 0.32 & 0.38 & 0.00 & 0.00 & 0.00 \\
\hline 14.00 & 2.58 & 0.01 & 2.86 & 2.20 & 0.00 & 2.33 & 0.00 & 0.00 & 0.01 & 4.00 \\
\hline 10.00 & 4.94 & 0.03 & 3.21 & 0.51 & 0.01 & 0.35 & 0.04 & 0.21 & 0.70 & 30.00 \\
\hline 10.00 & 5.03 & 0.04 & 3.27 & 0.33 & 0.00 & 0.35 & 0.01 & 0.23 & 0.75 & 30.00 \\
\hline
\end{tabular}

8. Bulk composition for the initial phase of garnet growth. Assumed a mode of $1.52 \%$ for the garnet core composition and $4.55 \%$ for the garnet rim composition.

9. Bulk composition for the post-hiatus phase of garnet growth. Assumed a mode of $0.00 \%$ for the garnet core composition and $0.607 \%$ for the garnet rim composition. 